\title{
Ukraine: Ex Post Evaluation of Exceptional Access Under the 2008 Stand-By Arrangement
}

This Ex Post Evaluation of Exceptional Access Under the 2008 Stand-By Arrangement with Ukraine was prepared by a staff team of the International Monetary Fund. It is based on information available at the time it was completed on July 6,2011. The views expressed in this report are those of the staff team and do not necessarily reflect the views of the government of Ukraine or the Executive Board of the IMF.

The policy of publication of staff reports and other documents allows for the deletion of marketsensitive information.

Copies of this report are available to the public from

International Monetary Fund $\bullet$ Publication Services

$70019^{\text {th }}$ Street, N.W. • Washington, D.C. 20431

Telephone: (202) 623-7430 • Telefax: (202) 623-7201

E-mail: publications@imf.org Internet: http://www.imf.org

\section{International Monetary Fund Washington, D.C.}


INTERNATIONAL MONETARY FUND

UKRAINE

\section{Ex Post Evaluation of Exceptional Access \\ Under the 2008 Stand-By Arrangement}

Prepared by an Interdepartmental Staff Team ${ }^{1}$

Authorized for Distribution by the European and

Strategy, Policy, and Review Departments

July 6, 2011

Contents

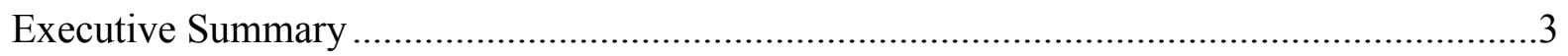

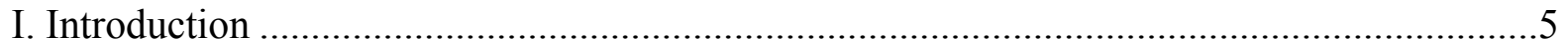

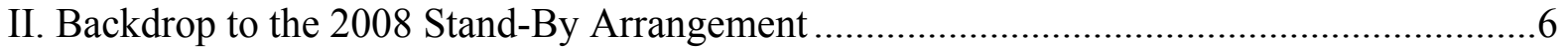

III. Program Design, Financing, and Exceptional Access Criteria ................................... 9

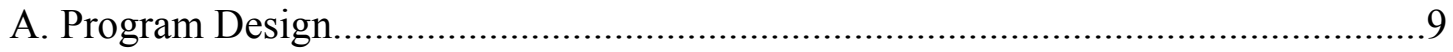

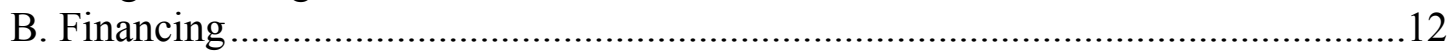

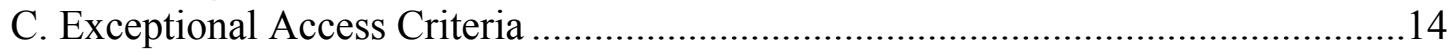

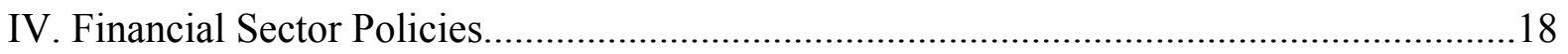

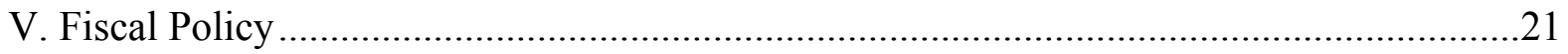

VI. Exchange Rate and Monetary Policy .................................................................25

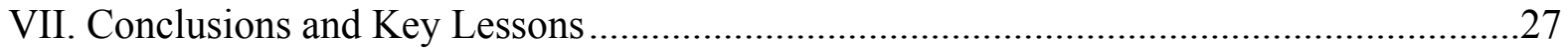

\footnotetext{
${ }^{1}$ The team comprised Andrea Schaechter (head, FAD), Fernando Montes-Negret (MCM), Stephane Roudet (EUR), and Ferhan Salman (SPR).
} 
Boxes

1. How Did the Program Deal with Risks?

2. Political Uncertainty Complicating Policy Implementation ............................................. 17

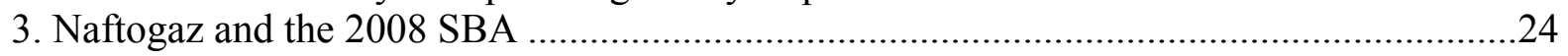

Appendices

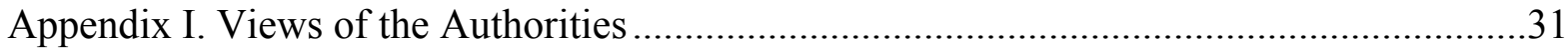

Appendix Table 1. Quantitative and Continuous Performance Criteria ................................32

Appendix Table 2. Prior Actions, Structural Conditionality, and Benchmarks......................33

Appendix Table 3. Key Political Developments, 2007: Q2-2010: Q2 ................................35

Appendix Table 4. Selected Economic Indicators, 2008-09 ….........................................36

Appendix Figure 1. Comparison of Macroeconomic Performance ........................................37 


\section{EXECUTIVE SUMMARY}

Ukraine faced a severe triple crisis in late 2008. Vulnerabilities had built up for years along several dimensions, but were masked by strong catch up growth and terms-of-trade windfalls. Tumbling steel prices and global demand as well as capital outflows triggered a balance of payments crisis, which also eroded confidence in the currency and the banking system. Despite low public debt levels, a fiscal crisis rapidly emerged on the back of a sharply contracting economy, the realization of contingent liabilities, and the lack of market access.

Ukraine was the third country to receive exceptional access support in early November 2008 under a front-loaded 24-month Stand-By Arrangement. The key program objectives were stabilizing the banking system and facilitating adjustment of the economy. As fiscal gaps emerged, and in view of the existing room under the programmed NIR targets, purchases were used for budget support, which proved critical, together with the currency counterpart obtained from a sale of the 2009 SDR allocation.

Accounting for the difficult circumstances - the need for quick action, little ownership, and weak governance and institutions - the program was overall well designed, however with compromises, for example regarding bank resolution, reflecting the program environment. Although structural conditionality was originally streamlined, reviews relied on an increasing number of prior actions in an attempt to enhance authorities' ownership and to address the emerging structural issues. Policy cornerstones of the program were measures to stem the banking crisis, a flexible exchange rate, and a significant degree of flexibility in fiscal policy.

Program implementation was difficult against the backdrop of sharp political divisions and weak institutional capacity. Only two of the envisaged eight reviews were completed. The program went off track in autumn 2009, as commitment vanished ahead of the January 2010 presidential elections and fiscal policy diverged further from the program. Nevertheless, the Fund remained closely engaged with the authorities.

Achievement of program objectives was mixed, with core short-term objectives largely met but little progress toward meeting medium-term objectives. The banking system stabilized, the current account adjusted quickly, social arrears and sovereign default were avoided, and a gradual economic recovery started from mid-2009. However, no major shift in policy making occurred and political economy considerations continue to drive policy making in Ukraine. Efforts to tackle the underlying structural and institutional weaknesses stalled. Bank resolution remained incomplete, the exchange rate regime returned to pre-crisis practices, the energy sector remained largely unreformed with quasi-fiscal deficits widening, and legal and governance reform fell short of objectives. The fiscal costs of the crisis and larger deficits to cushion the downturn have put large strains on Ukraine's public finances.

The key lesson from the EPE review is the importance of ownership and governance but there are no clear-cut answers on how to achieve this in Ukraine. Four signatories of the 
program, many prior actions, and close IMF involvement-including through significant technical assistance - were only partially successful. Less front-loading of the program may have provided a stronger incentive to follow through with policies but would have to be balanced against the need to secure confidence and adequate financing. 


\section{INTRODUCTION}

1. Ukraine was one of the countries hardest hit by the global economic and financial crisis; it was also one of the first countries supported by a Stand-By

Arrangement. Ukraine faced a triple crisis. Exposed by its strong reliance on steel exports, rising macroeconomic and private sector balance sheet imbalances, the simultaneous deterioration in its terms of trade, drop in external demand shock, and reversal of capital flows triggered a balance of payments crisis, which also eroded confidence in the banking system. On the heels of its sharp recession-Ukraine's real GDP dropped by 14.8 percent in 2009 — and without market access, a sovereign funding crisis followed. Ukraine was the third country to receive IMF financial support with exceptional access (after Georgia and Hungary) in November 2008, with financing originally focused on balance of payments needs, and over time, also on budget support.

Current Programs with Exceptional Access: Approval and Review Timelines

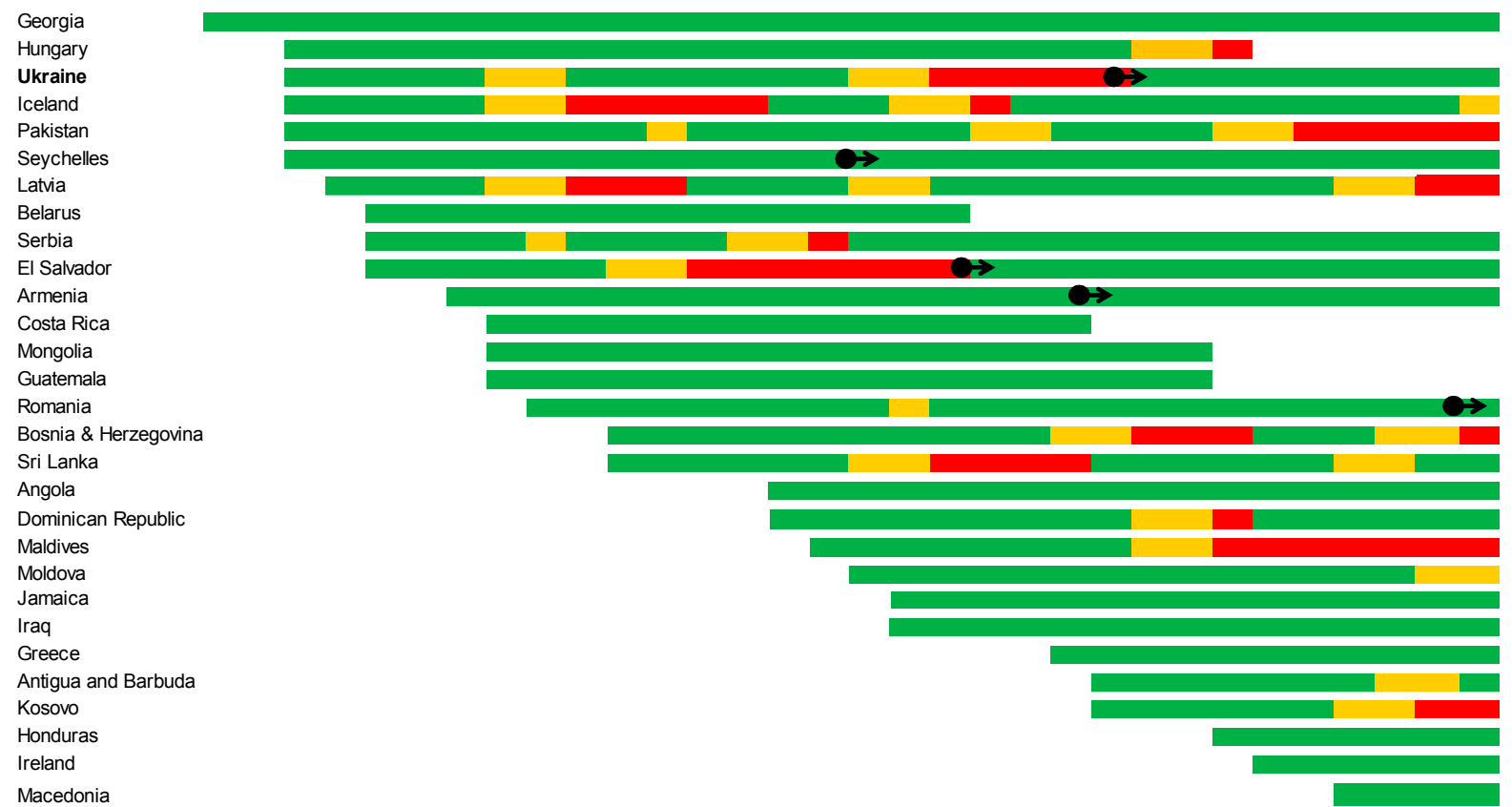

Sep Oct Nov Dec Jan Feb Mar Apr May Jun Jul Aug Sep Oct Nov Dec Jan Feb Mar Apr May Jun Jul Aug Sep Oct Nov Dec Jan Feb Mar Apr 2008

Program status: On track (review within 1 mı 2-3 months d $4+$ months delay

$\rightarrow$ Successor program

Source: IMF staff.

2. Program implementation was difficult against the backdrop of sharp political divisions. Only two of the envisaged eight reviews were completed, with the first review already delayed by three months due to failure to reach understanding on fiscal and bankingrelated policies in the midst of political wrangling between the president and the prime minister. In April 2009 agreement was reached after the authorities approved fiscal corrective measures, announced intervention and recapitalization of systemic problem banks, and 
revoked several policy measures which were not in line with the agreements under the program. After the second review was completed on time in June 2009-reflecting some progress with the bank resolution strategy, announcement of future plans to increase gas prices, the adoption of a restructuring strategy for Naftogaz, and a slowdown in foreign exchange interventions - the Fund remained closely engaged with the authorities. But the program went off track as ownership vanished and fiscal policy diverged further from the program. The new government requested a new SBA in support of its economic policy agenda, which was approved by the Board on July 28, 2010, at which point the 2008 SBA was cancelled.

3. This report assesses the effectiveness of the $2008 \mathrm{SBA}$, given the requirement for an evaluation in exceptional access cases. ${ }^{1}$ It addresses the following two questions: (i) were the macroeconomic strategy, program design, and financing appropriate and consistent with Fund policy; and (ii) did outcomes under the program meet program objectives. ${ }^{2}$

\section{BACKDROP TO THE 2008 STAND-BY ARRANGEMENT}

\section{Before the crisis, Ukraine experienced strong economic growth over many years} but its institutions remained weak. From 2000 to 2007, real GDP growth averaged

7.5 percent of GDP, one of the highest among transition economies, with a dent only in 2005 when steel prices fell by 30 percent in the first half of the year and credit growth slowed in

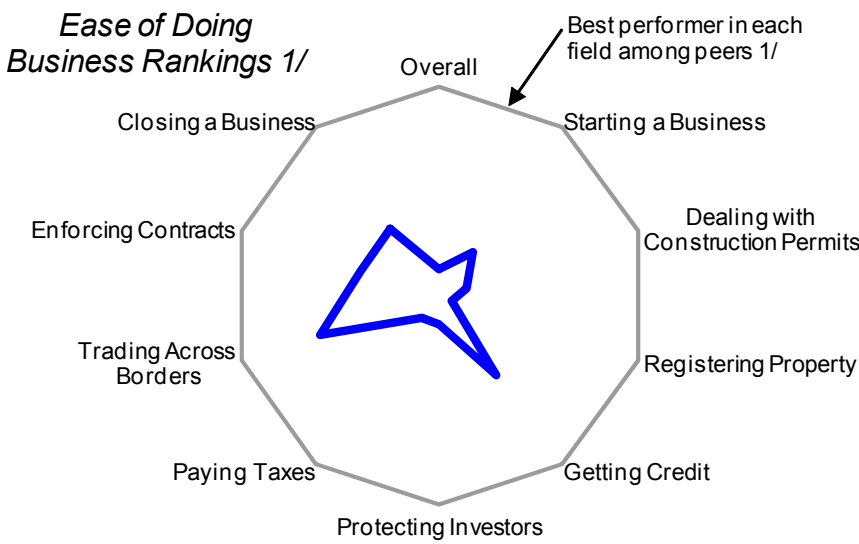

Sources: International Financial Corporation, Doing Business 2008. 1/ Ranking out of 15 CIS and CEE peers. CEE includes Czech Rep., Hungary, Poland, and Slovak Rep. Covers the period June, 2006 through May, 2007.

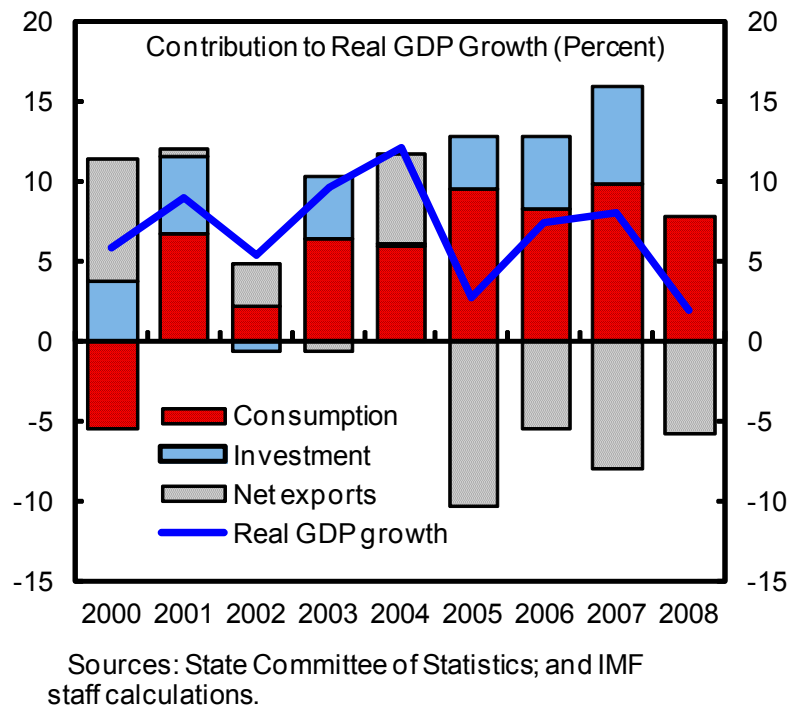

\footnotetext{
${ }^{1}$ See BUFF/03/28 and "Ex Post Evaluations of Exceptional Access Arrangements-Revised Guidance Note" (SM/10/44) (available at http://www.imf.org/external/np/pp/eng/2010/022510.pdf).

${ }^{2}$ In accordance with procedure, this report was prepared by an interdepartmental staff team, primarily on the basis of available documents and data. Naturally, this assessment benefits from hindsight. The team is grateful for conversations with present and former officials in Ukraine, and with present and former Fund mission chiefs and other Fund staff who were involved in the SBA. The key findings from the EPE were discussed with the authorities during a staff visit on June 7-9, 2011, and their general reactions are presented in Appendix 1.
} 
the aftermath of a near-banking crisis at end-2004. After the "Orange Revolution," expectations for institutional and policy reforms propelled FDI to Ukraine, particularly in the banking sector. However, the reform agenda moved forward only slowly.

\section{At the same time, vulnerabilities in the balance of payments as well as real and} financial sectors were building up. Ukraine's current account and growth performance relied strongly on favorable terms of trade. From 2003 to mid-2008, the price for steel, which accounted for 40 percent of Ukraine's export and 15 percent of GDP at the time of the crisis, had increased fourfold and prices for gas imports were still far below world market prices, providing little incentive to improve Ukraine's dismal inefficiency in energy use.

Nevertheless, by 2007 the current account had already deteriorated strongly as imports had surged on the back of a credit and real estate boom and an overheating economy. Private sector balance sheet imbalances widened sharply with foreign currency loans accounting for nearly 60 percent of total loans, often extended to borrowers without foreign exchange income, and bank funding increasingly relying on short-term borrowing from abroad.
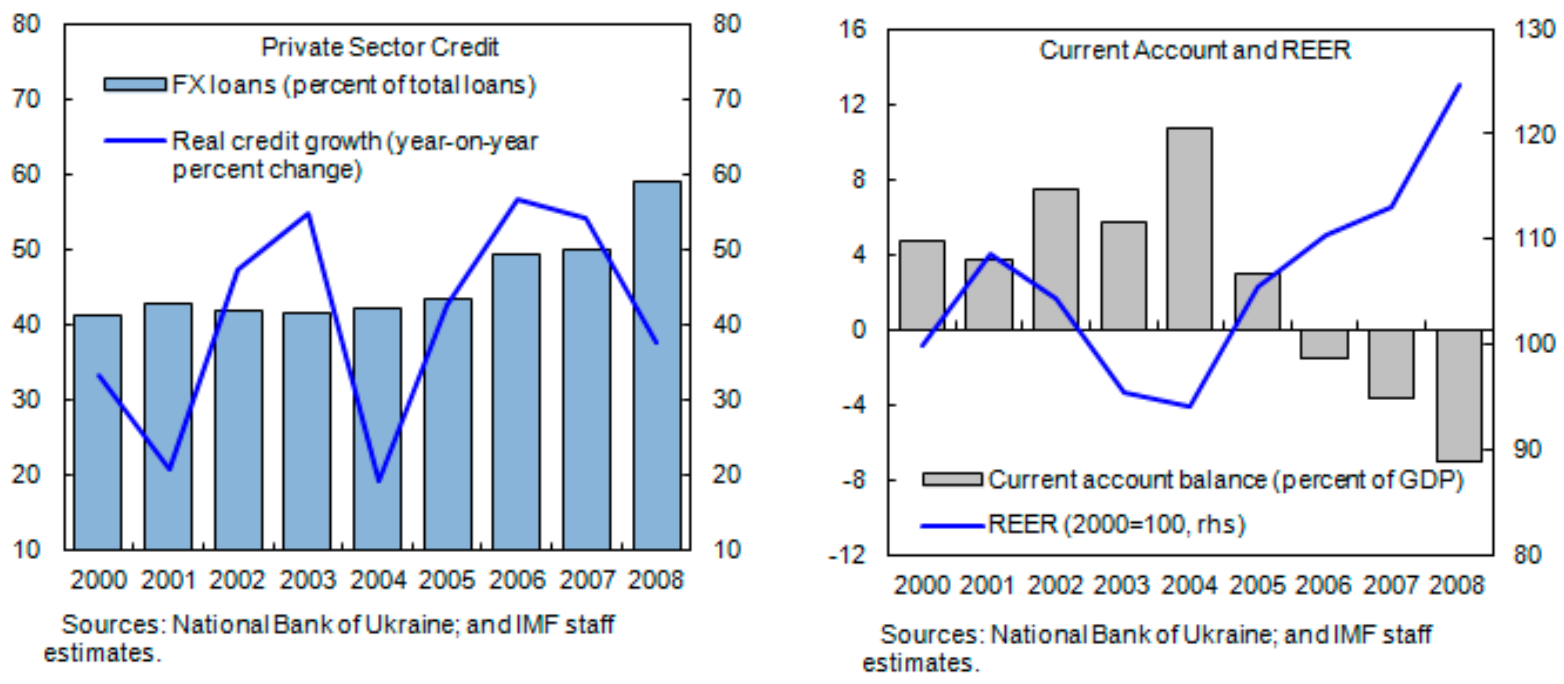

6. Macroeconomic policies and little progress on structural reforms aggravated the emergence of vulnerabilities. The fixed exchange rate regime encouraged foreign currency lending and the introduction of somewhat greater flexibility from March 2008 as well as modest NBU regulatory and supervisory efforts only partially helped to stem the risk buildup. At the same time, fiscal policy, in particular sharply expansionary incomes policies (e.g., public wages almost doubled in real terms between 2004 and 2008), fuelled consumption and contributed to the deterioration in the current account. Even

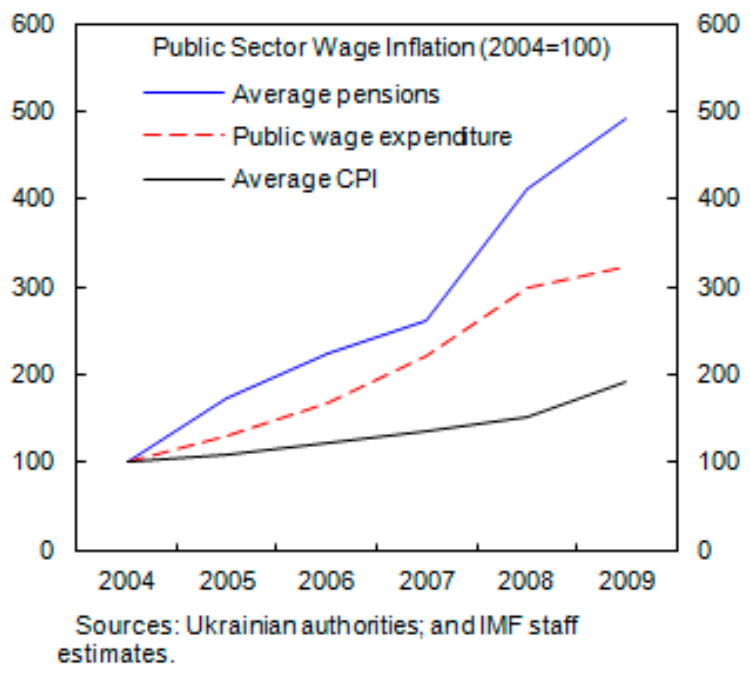


though public debt was low (12 percent of GDP in 2007), these policies contributed to additional budget rigidities and widened the structural fiscal challenges (e.g., Ukraine's public pension spending-to-GDP ratios exceeded 15 percent of GDP in 2008, one of the highest ratios worldwide).

7. Against this backdrop, Ukraine was hit in mid-2008 by severe terms of trade and external demand shocks, causing a balance of payments crisis. Steel prices tumbled by 80 percent between July and November 2008, supply sat idle in ports as demand vanished, and steel production was cut by over 20 percent in the second half of 2008. Adding to the terms of trade shock, Russia announced it would raise the heavily subsidized gas prices to Ukraine from 2009. When the global financial crisis spread, capital flows reversed and spreads for corporate and sovereign bonds surged.

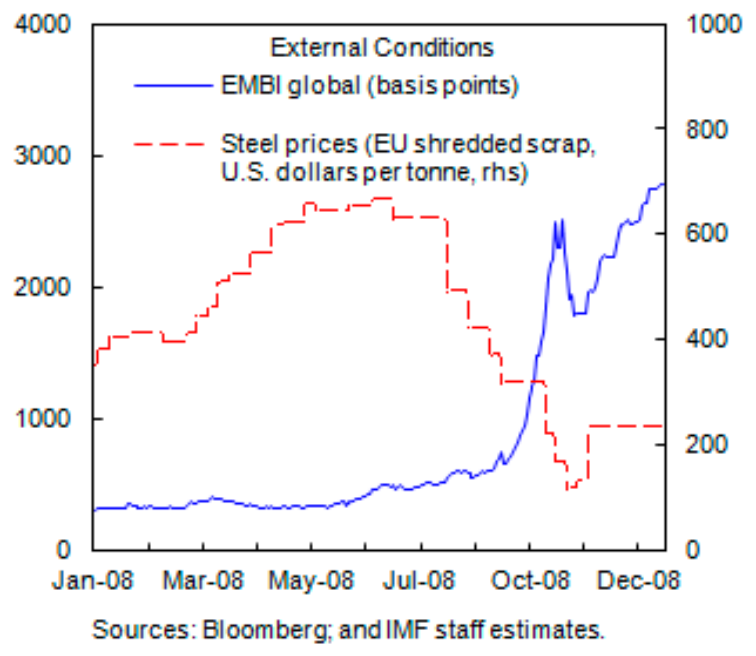

8. Pressure on the currency was exacerbated by the dwindling confidence in the banking system and the burst of the real estate and asset price bubble. Widespread deposit withdrawals followed a deposit run on the sixth largest bank Prominvest, which was put under receivership in October. The collapse of housing prices and the stock market (falling by 20 and 65 percent in the second half of 2008, respectively), intensified concerns about the banking system and the currency. In September/October, the NBU lost US $\$ 4.3$ billion (12 percent) of its reserves through interventions while the hryvnia's market rate depreciated by over 20 percent. The NBU injected 3.6 percent of GDP for liquidity support as the interbank market ceased functioning.

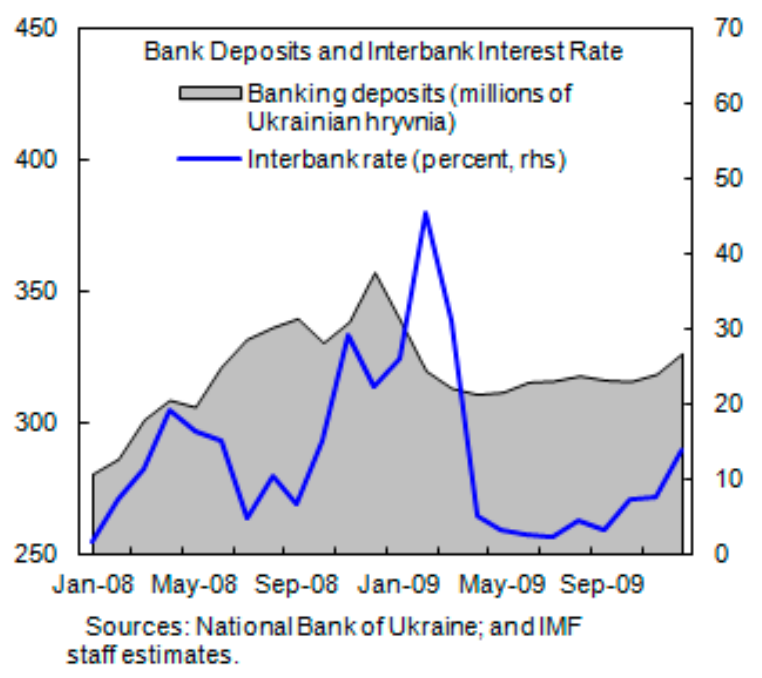

\section{Political instability complicated policy making in the run-up to the crisis and} later program implementation. Quick succession of governments with narrow majorities following the "Orange Revolution," political tensions between the president and prime minister, as well as representation of vested interests in parliament contributed to the delays in structural and institutional reforms as well as the increasingly ingrained role of incomes policy. In the midst of the crisis, political tensions flourished with the coalition collapsing in 
mid-September and the president announcing early elections initially scheduled for December 2008, heightening investor concerns (Box 2 and Appendix Table 3).

10. Many of the vulnerabilities and policy response options had been identified, before the crisis but not forcefully acted upon by the authorities. The Fund had warned for many years about rising banking sector vulnerabilities, the role of the fixed exchange rate regime for excessive risk taking, and advised on policies to address risks. ${ }^{3}$ Engagement included a range of technical assistance missions, the resident technical advisors, as well as regular support from headquarters and the resident representative office related to the authorities' policy considerations. The engagement was closely coordinated with the World Bank, including the joint 2002 FSAP and 2007 FSAP Update, which pointed to core vulnerabilities in the banking system. Concerns about the growth strategy had equally been raised by the Fund, most recently in the 2008 Article IV consultations which had also urged the authorities to build additional fiscal buffers. All in all, the Fund was well prepared for its crisis response in terms of policy requirements, although it had little insight into the weaknesses of individual banks given the opaqueness of the system and the lack of data provided by the authorities, and little grips on how to influence lasting policy change.

11. Ukraine had long but complicated program relations with the Fund. From 1994 to 2005, the Fund supported Ukraine through six arrangements. Completion of reviews tended to be difficult, as only 13 of the envisaged 24 reviews were completed, of which 10 with delay or involving waivers. The Ex Post Assessment of Longer-Term Program Engagement in 2005 (IMF Country Report No. 05/415) found that "Fund-supported programs had a mixed record in achieving their objectives. While the programs were quite effective in supporting macroeconomic stability, they did not succeed in accelerating the buildup of more market-friendly institutions." The report also drew three key lessons for future program engagement: "(i) program ownership is key and needs to be tested; (ii) political and administrative constraints argue for streamlined conditionality; and (iii) in terms of objectives, a program should focus on Fund core areas, i.e., strengthening and maintaining macroeconomic and financial stability."

\section{Program Design, Financing, And Exceptional Access Criteria}

\section{A. Program Design}

\section{In November 2008, the Fund approved a 24-month exceptional access SBA} (access of SDR 11 billion, equivalent to 802 percent of quota). The Fund responded quickly by implementing emergency financing procedures and approving the program within four weeks from the authorities' request for a mission. The two key objectives were (i) to

\footnotetext{
${ }^{3}$ See also IEO Background Paper BP 10/3 "IMF Performance in the Run-Up to the Financial and Economic Crisis: Bilateral Surveillance in Selected IMF Member Countries,” pp. 17-19.
} 
stabilize the domestic financial system against a backdrop of global deleveraging and domestic crisis of confidence; and (ii) to facilitate adjustment of the economy to large terms of trade shock. Fund financing was aimed to rebuild Ukraine's gross international reserves to cover at least 75 percent of short-term liabilities.

13. As the crisis evolved, the program focus shifted from the financial sector and exchange rate policy to fiscal policy.

- $\quad$ Restoring financial sector stability appropriately built on a number of measures under the program. These included (i) provision of NBU liquidity support to the banking system; (ii) preparation and implementation of a bank resolution strategy; and (iii) strengthening the framework for household and enterprise debts.

- To facilitate economic adjustment and closing the balance of payments gap, a mix of macroeconomic policies was agreed. These included (i) a flexible exchange rate policy, supported by base money targets, and gradual transition to inflation targeting; (ii) resetting incomes policy in line with targeted inflation, while protecting the most vulnerable; (iii) maintaining a prudent fiscal stance; and (iv) bringing energy sector prices more in line with costs.

- Acknowledging the exceptional degree of macroeconomic uncertainty the program built in a large degree of flexibility for fiscal policy. Even more so than in many other countries, the impact of the global crisis on real GDP and fiscal revenue was underestimated. However, as financing constraints emerged on the back of revenue shortfalls and lack of capital market access, the program allowed automatic stabilizers to work and provided budget support.

14. Program conditionality reflected the changing priorities as well as attempts to ensure commitment as political divisions took hold. The program, in terms of objectives and conditionality, reflected much of the earlier EPA recommendations. In line with streamlined structural conditionality, it included four prior actions, three structural performance criteria, and three structural benchmarks (in addition to three quantitative performance criteria and four continuous performance criteria). By the time of the first review, the number of prior actions had grown from four to seven and structural benchmarks from three to eight, while structural performance criteria were dropped consistent with the new Fund's conditionality reform (Appendix Table 2). The use of a large number of prior actions was an attempt to ensure critical policy implementation at a time when political environment had become more polarized as well as to emerging need to address mediumterm structural problems, including ensuring fiscal sustainability. 


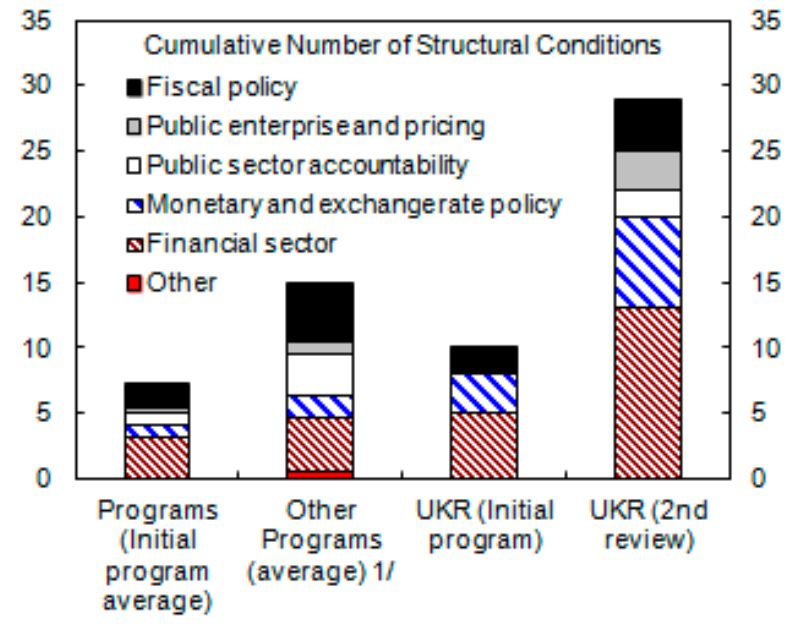

Sources: IMF, MONA database; and IMF staff estimates and calculations.

$1 /$ Total structural conditionality is measured across all reviews.

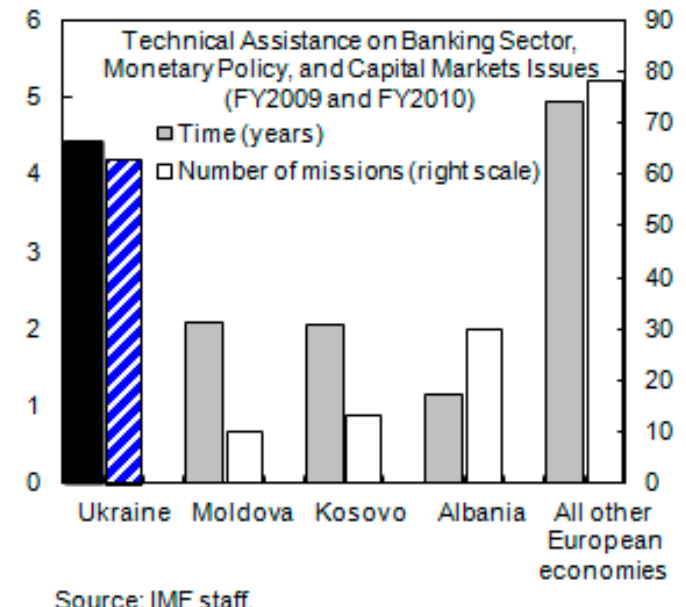

Source: IMF staff.

\section{Box 1. How Did the Program Deal with Risks?}

Implementation risk. Implementation risk was acknowledged from the outset, though it could have featured more prominently in the first staff report as the program was agreed at a time when no coalition agreement was in place. However, the four signatories of the program - the president, prime minister, minister of finance, and central bank governor-assured their support as did the opposition to which the Fund staff presented the program in a parliamentary session. The large and rising number of prior actions and nearly daily contact with the authorities at the highest political and technical levels were attempts to keep policies on track.

Macroeconomic risks. Given the exceptional uncertainty about the global economic developments and their impact on the Ukrainian economy, the program allowed from the start to adjust fiscal deficit targets. The envisaged flexible exchange rate was designed as a buffer for the large uncertainty about the balance of payments shock and the macroeconomic imbalances. The shift to budget support addressed the changing nature of the crisis.

Risk for Fund resources. Even though the SBA was large and front-loaded, the size, eventual phasing, and quarterly reviews took into account the risk for Fund resources. In particular, the program aimed for 75 percent short-term debt coverage (lower than in other countries) and disbursement at the delayed first review reflected a re-phasing with lower disbursement than originally foreseen by May. The need for governance reforms at the NBU was acknowledged at the outset of the program. This was underscored by the findings and recommendations of the safeguards assessment carried out in December 2008. In particular, the NBU agreed to an external review of liquidity and foreign exchange operations conducted during the fourth quarter of 2008, and Ernst\& Young (Kiev) was subsequently engaged to perform certain agreed-upon review procedures and report its factual findings to the NBU, which it did shortly before the second review. However, in line with international auditing standards for this type of engagement, Ernst \& Young provided no conclusions or audit assurances and the report included only its factual findings in regard to the specific procedures and period of review agreed with the NBU. 


\section{To support policies agreed under the program, the Fund was closely engaged} with the authorities. In particular, in the core program areas of financial sector resolution and exchange rate policy, massive technical assistance was provided, accounting for about 30 percent of all technical assistance resources provided in those areas to European countries. At the same time, the Fund gave almost continuous support from headquarters and via the resident representative office and, as political divisions became deeper, was increasingly drawn in as a facilitator among the parties. In late December 2009 when the program was already off track and presidential elections were only weeks away, the Board lowered the performance criterion for the end-2009 net international reserve (NIR) floor to enable the authorities to use existing resources to make external payments due, including gas payments.

\section{B. Financing}

16. To address the immediate balance of payments financing need and reestablish confidence in banking system, the SBA had high access and was frontloaded. The financing package was set at 802 percent of the quota and was one of the largest programs when measured in percent of GDP, with a first upfront disbursement of 218.7 percent. Frontloading was somewhat smaller than in most other programs, reflecting in part the high implementation risk. Delays in the first review motivated a re-phasing of financing that slightly reduced the frontloading. Disbursements were rephased to May 1, 2009 and June 15, 2009 to compensate for delays in February and May, and the November access level was adjusted to keep the total access level at SDR 11 billion (Table 1). In total, the three disbursements amounted to 501.3 percent of quota or 63 percent of the envisaged total amount.

\section{Access and Phasing in Current Crisis}
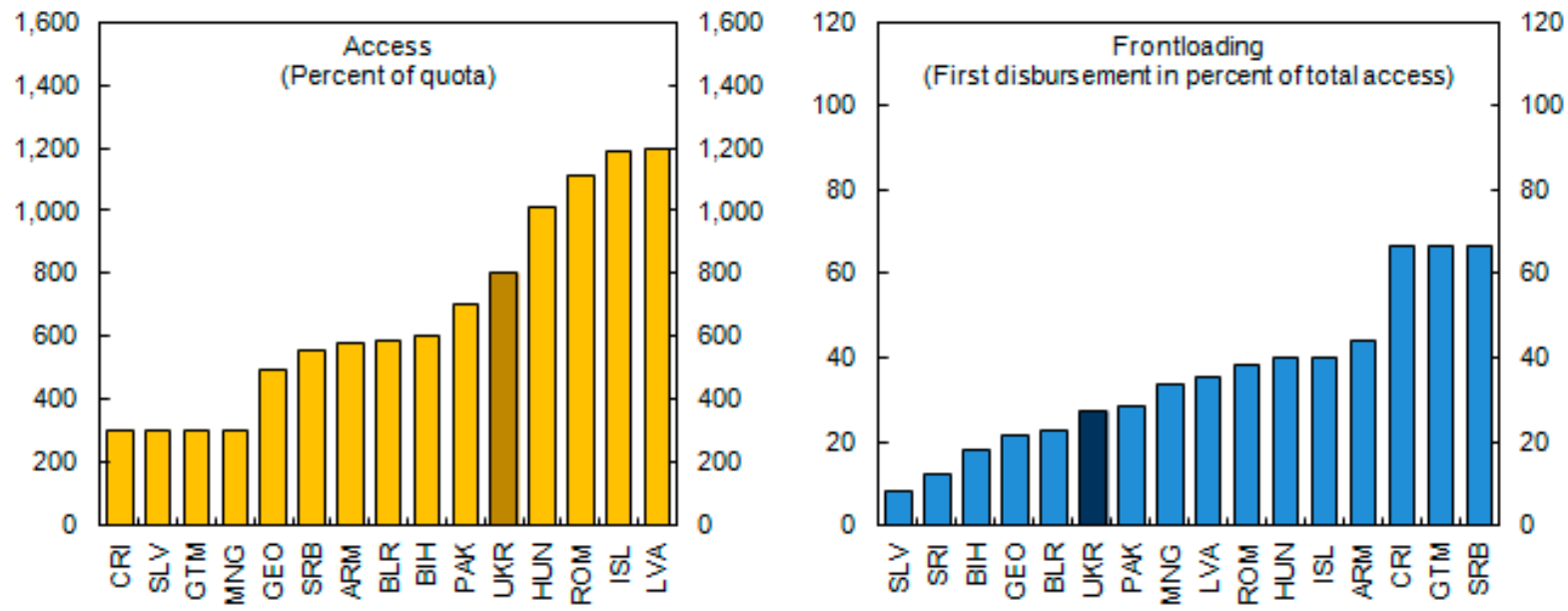
Access and Phasing Under the Stand-By Arrangement

\begin{tabular}{|c|c|c|c|c|c|c|}
\hline \multirow[b]{2}{*}{ Date available } & \multicolumn{2}{|c|}{ Original Program } & \multicolumn{2}{|c|}{ First Review } & \multirow[b]{2}{*}{ Conditions include } & \multirow[b]{2}{*}{ Status } \\
\hline & $\begin{array}{l}\text { In millions } \\
\text { of SDRs }\end{array}$ & $\begin{array}{l}\text { In percent } \\
\text { of quota }\end{array}$ & $\begin{array}{l}\text { In millions } \\
\text { of SDRs }\end{array}$ & $\begin{array}{l}\text { In percent } \\
\text { of quota }\end{array}$ & & \\
\hline Nov. 2008 & 3,000 & 218.7 & & & Board approval of arrangement & \\
\hline 15 Feb. 2009 & 1,250 & 91.1 & & & $\begin{array}{l}\text { Observance of end-December performance criteria } \\
\text { and completion of the first review }\end{array}$ & Delayed \\
\hline 1 May 2009 & & & 1,875 & 136.7 & $\begin{array}{l}\text { Observance of end-March } 2009 \text { performance criteria, } \\
\text { prior actions and completion of the first review }\end{array}$ & Completed \\
\hline 15 May 2009 & 2,500 & 182.2 & & & $\begin{array}{l}\text { Observance of end-March performance criteria and } \\
\text { completion of the second review }\end{array}$ & Delayed \\
\hline 15 Jun. 2009 & & & 2,125 & 154.9 & $\begin{array}{l}\text { Observance of end-May } 2009 \text { performance criteria, } \\
\text { prior actions and completion of the second review }\end{array}$ & Completed \\
\hline 15 Aug. 2009 & 750 & 54.7 & & & $\begin{array}{l}\text { Observance of end-June performance criteria and } \\
\text { completion of the third review }\end{array}$ & Delayed \\
\hline 15 Nov. 2009 & 2,000 & 145.8 & 2,500 & 182.3 & $\begin{array}{l}\text { Observance of end-September performance criteria } \\
\text { and completion of the fourth review }\end{array}$ & Delayed \\
\hline 15 Feb. 2010 & 375 & 27.3 & & & $\begin{array}{l}\text { Observance of end-December performance criteria } \\
\text { and completion of the fifth review }\end{array}$ & Delayed \\
\hline \multicolumn{7}{|c|}{$\begin{array}{l}\text { Quantitative and structural performance criteria for remaining scheduled purchases in } 2010 \text { are expected to be established at the time of } \\
\text { the third review. }\end{array}$} \\
\hline 15 May 2010 & 375 & 27.3 & & & $\begin{array}{l}\text { Observance of end-March performance criteria and } \\
\text { completion of the sixth review }\end{array}$ & \\
\hline 15 Aug. 2010 & 375 & 27.3 & & & $\begin{array}{l}\text { Observance of end-June performance criteria and } \\
\text { completion of the seventh review }\end{array}$ & \\
\hline 15 Oct. 2010 & 375 & 27.3 & & & $\begin{array}{l}\text { Observance of end-September performance criteria } \\
\text { and completion of the eighth review }\end{array}$ & \\
\hline Total & 11,000 & 802 & 11,000 & 802 & & \\
\hline
\end{tabular}

\section{As budget financing pressure} emerged, and in view of the existing room under the programmed NIR targets, purchases were used for budget support. The stronger-than-expected current account adjustment due to sharp import retrenchment, combined with relatively good rollover rates, provided room for Ukraine received 223 percent of its quota as direct budget support, comparable to other programs. At the time of the first review, half of the disbursement went into budget support; by the time of

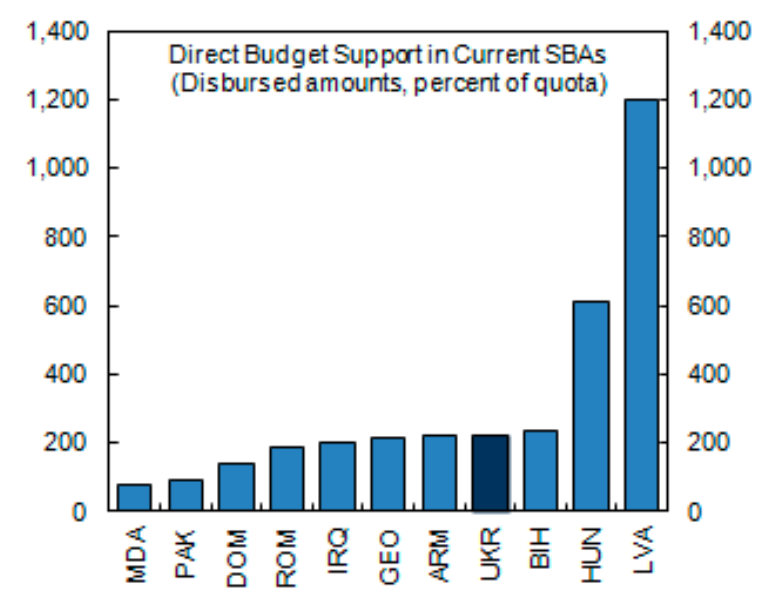

Source: IMF staff. the second review, the full disbursement was channeled to the government to meet its financing obligations, including gas payments. Moreover, in the second half of 2009, the currency counterpart (US\$1.3 billion) from a sale of the SDR allocation also went to the budget. 
18. Other donors played a subordinate role in closing Ukraine's financing gap. At the time of the program, disbursements from the World Bank of about US\$800 million for budget support, under the Country Partnership Strategy (with total commitments of US\$1.56 billion over four years), were factored in. However, only about half materialized in 2009as structural, institutional, and governance reforms progressed only slowly—putting the financing support squarely on the back of the Fund. The EBRD's engagement focused on investment in the banking system and the corporate sector.

19. Overall, the size of IMF financing under the program proved sufficient. Given the delays in program implementation and review, the authorities faced funding constraints but these were alleviated by the sales of the SDR allocation. A quicker-than-expected current account adjustment and strong rollover rates also helped.

\section{Exceptional Access Criteria}

20. In line with the exceptional access procedures at the time, the SBA request was assessed in light of the exceptional access criteria. Since Ukraine's program was approved before the Board decisions that modified exceptional access criteria (GRA Lending Toolkit and Conditionality-Reform Proposals, 3/19/09), its request for exceptional access is assessed under the old criteria for exceptional access (PIN 03/37, 3/21/03):

- $\quad$ First criterion: "the member is experiencing exceptional balance of payments pressures on the capital account resulting in a need for Fund financing that cannot be met within the normal limits." Ukraine faced a severe capital and current account crisis as well as sharp withdrawal of bank deposits (Section II). Not only were the shocks that the Ukrainian economy faced massive, but the uncertainty about the global outlook and its implications for Ukraine were exceptionally high.

- $\quad$ Second criterion: "a rigorous and systematic analysis indicates that there is a high probability that debt will remain sustainable." Baseline external and public debt sustainability analysis (DSA) indicated that the economy could absorb considerable foreign and domestic liabilities without threatening external and fiscal sustainability. However, stress tests also indicated that debt ratios would be particularly sensitive to a sharp growth shock and the realization of contingent liabilities. Public debt eventually accounted for about 30 percent of GDP (excluding IMF disbursements to the NBU) at end-2009, almost double the initial projection, reflecting the more severe 


\section{Projected External and Public Debt Under the Baseline}
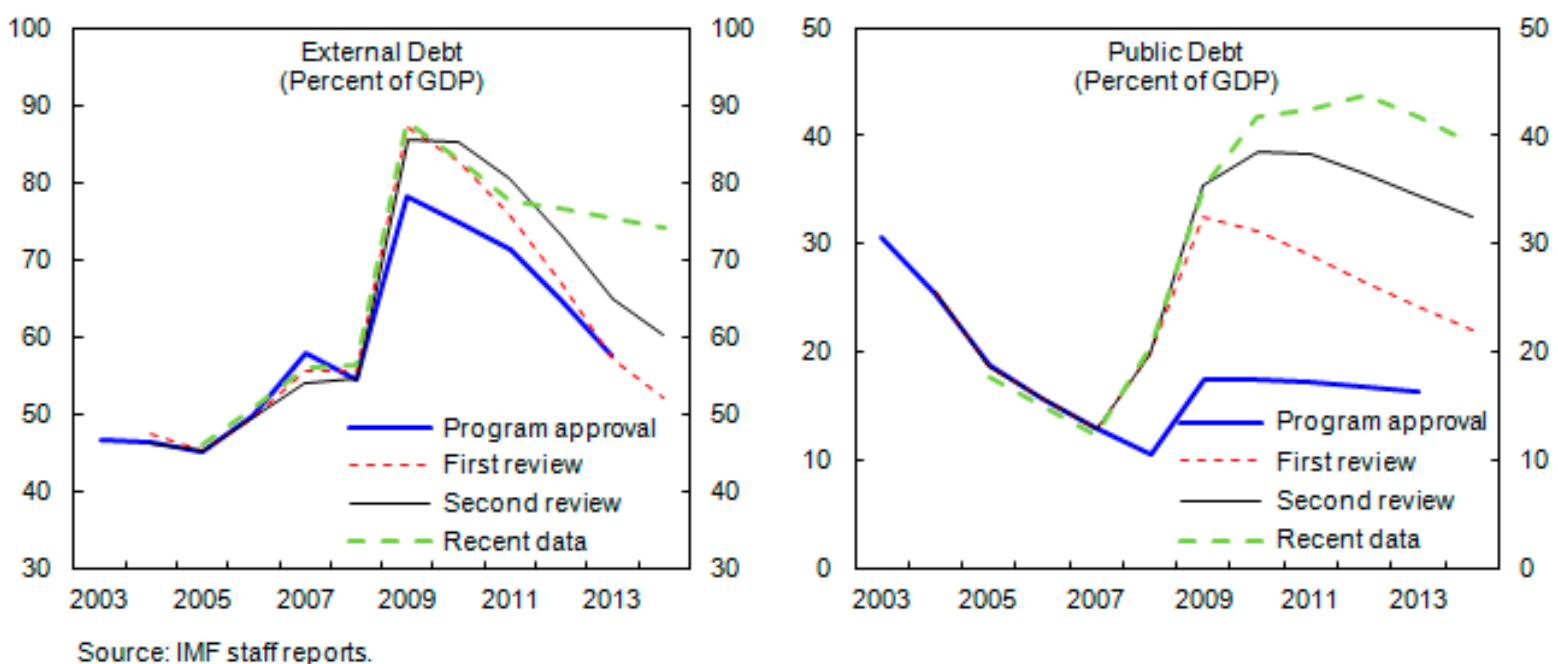

economic contraction and the higher-than-expected deficit, but also the unforeseen realization of contingent liabilities in the gas sector. At end-2009, the ratio of external debt to GDP ( 88 percent of GDP) was also 10 percentage points higher than initially envisaged, reflecting the lower base.

- $\quad$ Third criterion: "the member has good prospects of regaining market access within the time that Fund resources would be outstanding, so that the Fund's financing would provide a bridge." With confidence stabilizing, good prospects were seen for the private sector to regain market access. Given the large strategic presence of foreign banks and large holdings of financial assets by Ukrainian corporates abroad, the program assumed relatively high rollover rates (85 percent) which broadly materialized. The Fundsupported program clearly played a role for investor confidence and contributed to moderating sovereign EMBI spreads at the time of the program approval and first and second

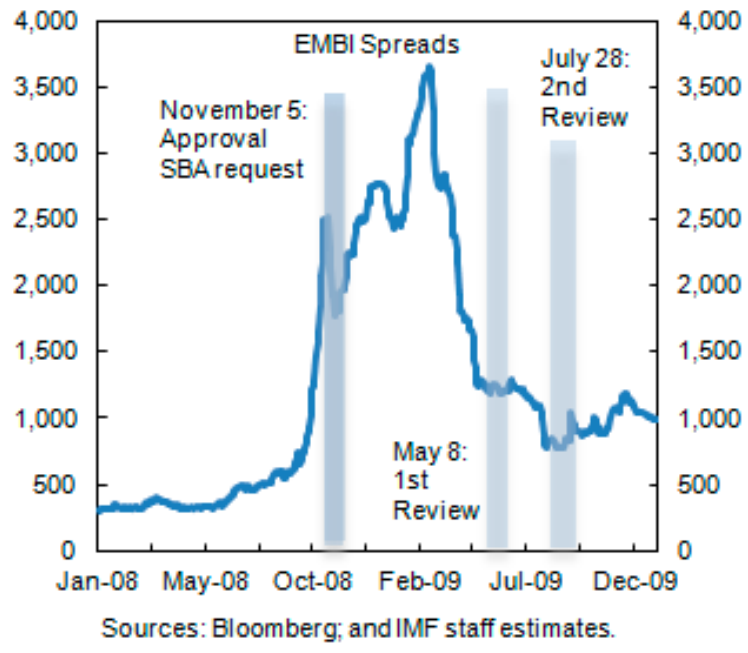
reviews, but spreads surged during the delay of the first review, a time that also coincided with tensions related to gas payments to Russia. With spreads still high, the sovereign regained access to international markets only under a new government in September 2010 when it issued a US\$2 billion Eurobond. It became difficult for the government to raise funds in domestic markets in the run-up to the presidential elections, with the third review 
being delayed. But yields on domestic government securities, which exceeded 20 percent, have gradually decreased since then to around 10 percent.

- $\quad$ Fourth criterion: "the policy program of the member provides a reasonably strong prospect of success, including not only the member's adjustment plan but also its institutional and political capacity to deliver that adjustment." The policies and reforms targeted under the program were strong, but risks to the program were considerable (Box 1). Attempts to mitigate the implementation risk, which was particularly high given the fragmented political environment (Box 2), included a frontloading of policy measures via prior actions and involvement of all key stakeholders. In hindsight, institutional and political capacity proved sufficient to largely achieve the major short-term program objectives to stem the crisis and restore confidence, however falling short on a number of agreed-upon policies and leaving core structural vulnerabilities unaddressed.

21. A report assessing the risks to the Fund and the Fund's liquidity position was provided to the Board consistent with exceptional access procedures. The "risks and impact report" highlighted Ukraine's poor track record and historically weak ownership in addition to "considerable financial risks associated with the proposed arrangement for Ukraine." The Board was involved early in the lead up to the request of the program and briefed on October 22, 2008. The staff reports and the authorities' Letter of Intent and Memorandum of Economic and Financial Policies were published. 


\section{Box 2. Political Uncertainty Complicating Policy Implementation}

Political risk was particularly high at the time of the program request. The period following the 2005 "Orange Revolution" had been characterized by a succession of short-lived governments, generally supported by narrow majority coalitions. In autumn 2008, political tensions had surged: President Yushenko's bloc in parliament withdrew from the governing coalition with Prime Minister Tymoshenko in September, the president dissolved parliament on October 8 - two weeks before the program request - and called for early elections, initially scheduled for December 2008. In addition, the prospect of the presidential election-which had to take place a year later and in which the president, prime minister, and the leader of the opposition were going to compete-was looming, prompting political analysts to underscore the increasing political risk.
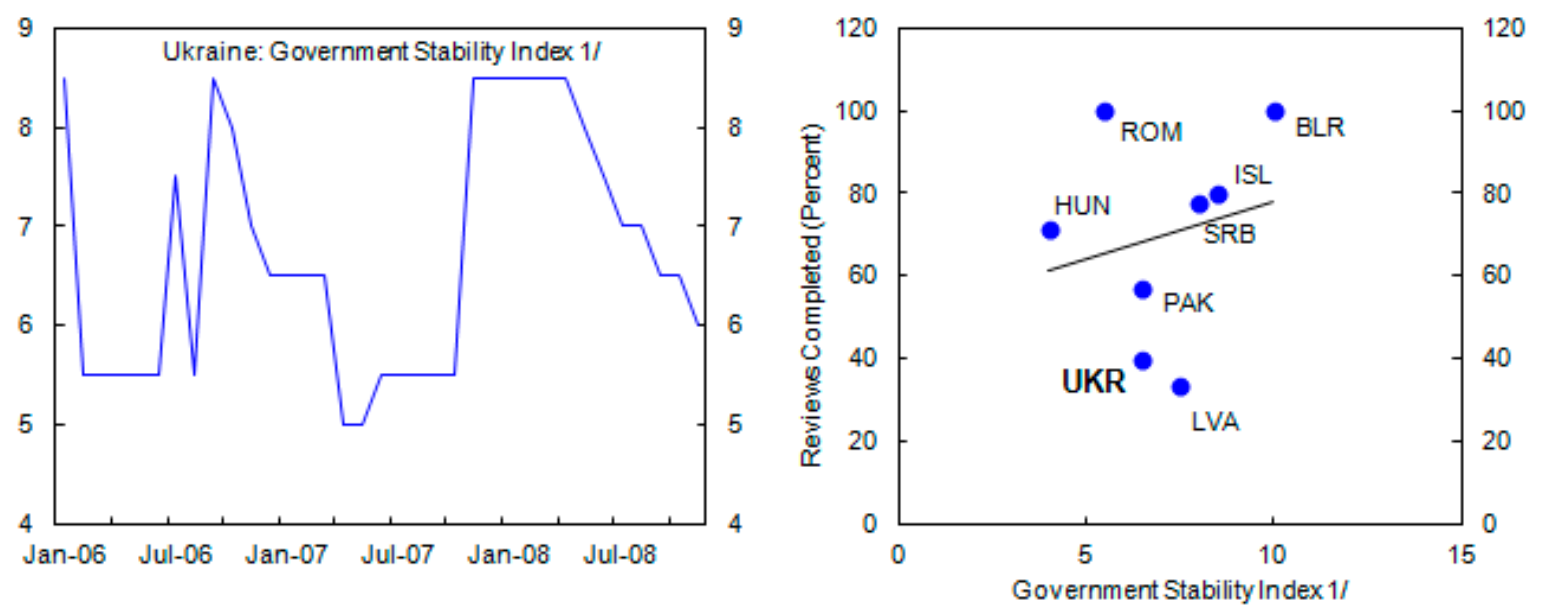

Sources: The PRS Group, International Country Risk Guide; and IMF staff estimates.

$1 /$ The index measures the government's ability to carry out its declared program and its ability to stay in office. A higher index (ranging from 0 to 12 ) indicates more stability.

As the program advanced, heightened political instability complicated policy making and program implementation. Although the October 2008 political crisis was resolved with a threeparty coalition agreement and without parliamentary elections, intense political wrangling continued throughout the program (for a detailed account of the political developments, see also Appendix Table 3). The minister of finance resigned in early 2009; several MPs close to the president were sacked by parliament; and parliament voided its 2004 appointment of NBU Governor Stelmakh with the governor going temporarily on leave. In the second half of 2009, the consensus within the coalition in favor of the SBA-supported economic program in effect collapsed. The government submitted in September 2009 a highly unsustainable draft 2010 budget to parliament. Another coalition partner supported a bill to increase the minimum wage and pension substantially. And the leader of the third coalition partner- the president - refused to veto this law. 


\section{Financial Sector Policies}

\section{Policies to restore financial sector stability were a cornerstone of the program.}

Conceptually, the approach followed traditional crisis resolution methods along the following four modules: (i) restoring liquidity by reducing reserve requirements and providing NBU emergency liquidity assistance, containing deposit outflows by tripling the deposit insurance coverage (to UAH 150,000), and prohibiting the early redemption of time deposits;

(ii) putting in place a triage system consisting of diagnostics of large, systemically important banks in order to determine their viability, assessing recapitalization needs, and resolving nonviable banks; (iii) strengthening bank monitoring, increasing the frequency of NBU targeted on-site inspections, and improving cross-border supervisory cooperation; and (iv) improving financial disclosure.

\section{Many aspects of the bank}

resolution strategy entered program conditionality. One set of required actions reflected measures to address the existing legal, regulatory, and institutional weaknesses for bank resolution, the opacity and quality of financial information and ultimate bank ownership, and NBU independence and governance (Appendix Table 2). The other set focused on implementing the resolution strategy, starting with finalizing the resolution of the sixth largest bank, Prominvest, completing

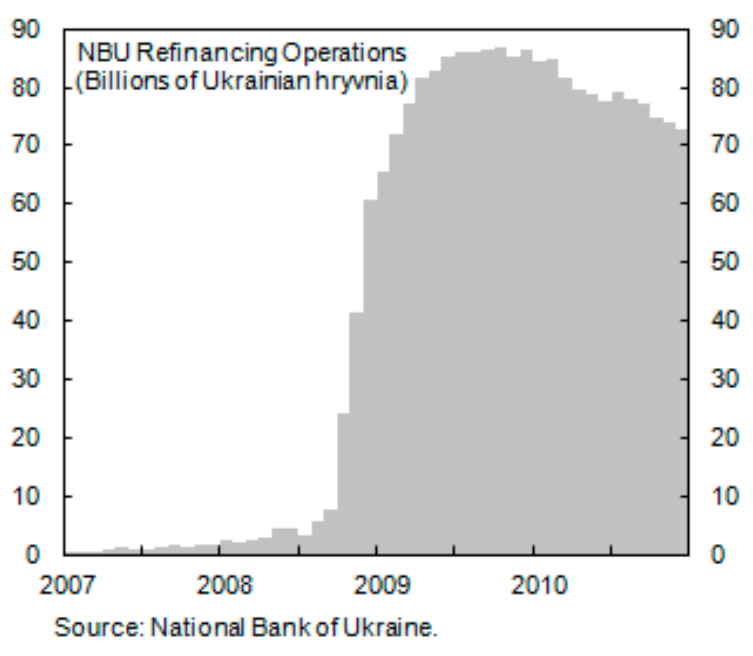
diagnostic studies, and starting to resolve systemic problem banks. ${ }^{4}$

\section{The program also covered NBU liquidity support but not all concerns were fully alleviated.}

- $\quad$ Transparency of refinancing and foreign exchange operations: In line with recommendations of the safeguards assessment to seek assurances about the integrity of the NBU operations, a review by a reputable audit firm was completed prior to the second review. However, the report—prepared in a short period of time—was limited in scope and, in line with international auditing standards for this type of engagement, did not include conclusions or a provision of assurance (Box 1). For the latter, a much more comprehensive and time-consuming assessment would have been needed.

\footnotetext{
${ }^{4}$ The initial program included a structural performance criterion on "resolving all problem banks by end-June 2009." By the second review, progress on bank resolution was tied to "finalizing the resolution strategy for each of the non-systemic problem banks and starting implementation by end-September 2009."
} 
- $\quad$ Liquidity provided to insolvent banks: As it was difficult to distinguish between solvent and nonviable banks, liquidity support was likely extended to the latter. Moreover, the maturities of NBU loans, which originally ranged from 14 to 365 days, were later converted up to seven years providing de facto solvency support.

- Relaxation of collateral requirements: Banks' own shares were accepted as eligible collateral despite the significant risk for the NBU.

- $\quad$ Mandatory purchases of bank recapitalization bonds: The NBU was required to purchase at face value recapitalization bonds issued by the government, a practice that the Fund staff advised against.

25. All in all, the NBU was exposed to substantial financial risk. By end-2009, its assets included 9.2 percent of GDP of liquidity support for which it had provisioned 2.7 percent of GDP. The risk was originally compounded by the lack of a timely ex post audit of its exposure and potential asset impairment, as the NBU's external Auditor's Report for 2008 was qualified with respect to the fair value of the loans granted to banks.

26. The authorities initially made good progress in diagnosing banks' financial conditions. Based on a forward-looking methodology, agreed by financial sector experts of the IMF and World Bank and involving portfolio stress tests to capture the expected further deterioration of the banks' loan portfolios and depletion of the capital buffers, the authorities commissioned bank auditors to undertake bank extended audits. These were completed for the 34 largest banks by January 5, 2009 and for the other banks by end-May 2009.

\section{However, in light of the need to act swiftly, political resistance, and weak} institutional capacity, compromises were made in some areas. Given the time constraints, the diagnostics were limited in scope and uneven in quality. Also, the authorities insisted on a definition of "systemic banks" that was rather broad and included banks with at least 2 percent market share (in percent of total bank assets) and at least 1 percent of total household deposits, arguing that failure of these bank could have contagion effects. These criteria applied to 26 of the 180 banks. At the time, the program erred on the side of caution which allowed to pushing the strategy forward in light of political resistance. In hindsight, however, a strategy focusing on recapitalizing a smaller group of thoroughly audited large banks, while liquidating smaller nonviable banks, may have been preferable for creating a sound system for the medium term, and possibly less costly given the risk of repayment of NBU liquidity support and remaining medium-term vulnerabilities.

28. For the same reasons, minimum legal and institutional provisions were made at the outset of the process, while more comprehensive legal reforms were put into place only later. Important prior actions were legal amendments authorizing the NBU to undertake the necessary bank resolution process and the adoption of the so-called "Anti-Crisis Law." The law provided the general framework for the recapitalization of the banking system and defined the modalities of the government's participation in the bank recapitalization process. 
These basic tools allowed starting the recapitalization program, but other key bank resolution tools were not granted until legal changes were passed in late July $2009,{ }^{5}$ in part complicated by the large presence and influence of bank owners and major bank shareholders in parliament. Moreover, NBU governance reform (a structural benchmark for end-June 2009) stalled. While some amendments were passed by March 2009, they did not address commitments regarding NBU independence, governance, and transparency under the program.

29. After a good start, the bank resolution program progressed more slowly than envisaged under the program. After a decision by the government not to liquidate any of the systemic problem banks, resolution strategies for three systemic private banks were finalized only by the time of the second review. Also, the diagnostic reports to determine the capital needs of the two state-owned banks were completed only in 2010. Earlier capital injections via recapitalization bonds (in 2008 and partly in 2009) in these two banks served mainly for on-lending, in particular to public enterprises, including Naftogaz. For other banks, progress was also uneven but, given the capacity constraints, the NBU focused largely on the systemic banks. Most systemic and foreign banks injected the necessary regulatory capital as scheduled while some other banks lagged behind as the NBU did not always strongly enforce the first round of capital increases. Eventually, however, most banks injected the requested capital. Several problem banks, including one systemic bank (Nadra) were not resolved under the program.

\section{Overall, the program achieved one of its key objectives-restoring short-term} stability and confidence in the banking system - but the system remains vulnerable and bank resolution incomplete. When measured in terms of deposits outflows, it took some time to reach this goal, however. Hryvnia-denominated deposits experienced a "double dip," while foreign currency-denominated deposits recovered earlier (as there were conversions from hryvnia to U.S. dollar deposits). Also, the direct fiscal costs for stabilizing the banking system were significant, though below those associated with earlier banking crises in other countries, which averaged about 14 percent (Laeven and Valencia, 2008). By end-2009, recapitalization costs amounted to about 4.5 percent of GDP. This is similar to the net direct costs associated with financial sector support in countries such as Greece, the Netherlands, and the United Kingdom (see the April 2011 Fiscal Monitor). There is a risk, however, that the ultimate fiscal costs of the banking crisis in Ukraine might still rise given that many banks continue to have weak balance sheets with high levels of non-performing loans, and large amounts of NBU stabilization loans are still outstanding. Little progress was also made in strengthening the framework for household and enterprise debt restructuring, one objective in the initial program, given the protracted legal reforms.

\footnotetext{
${ }^{5}$ The changes created the specific tools to deal with banks in distress, including reorganization of banks, transfer of bank property, write downs of capital prior to recapitalizations (shareholders' dilution), creation of bridge banks, as well as new and stronger powers for NBU temporary administrators and bank liquidators.
} 

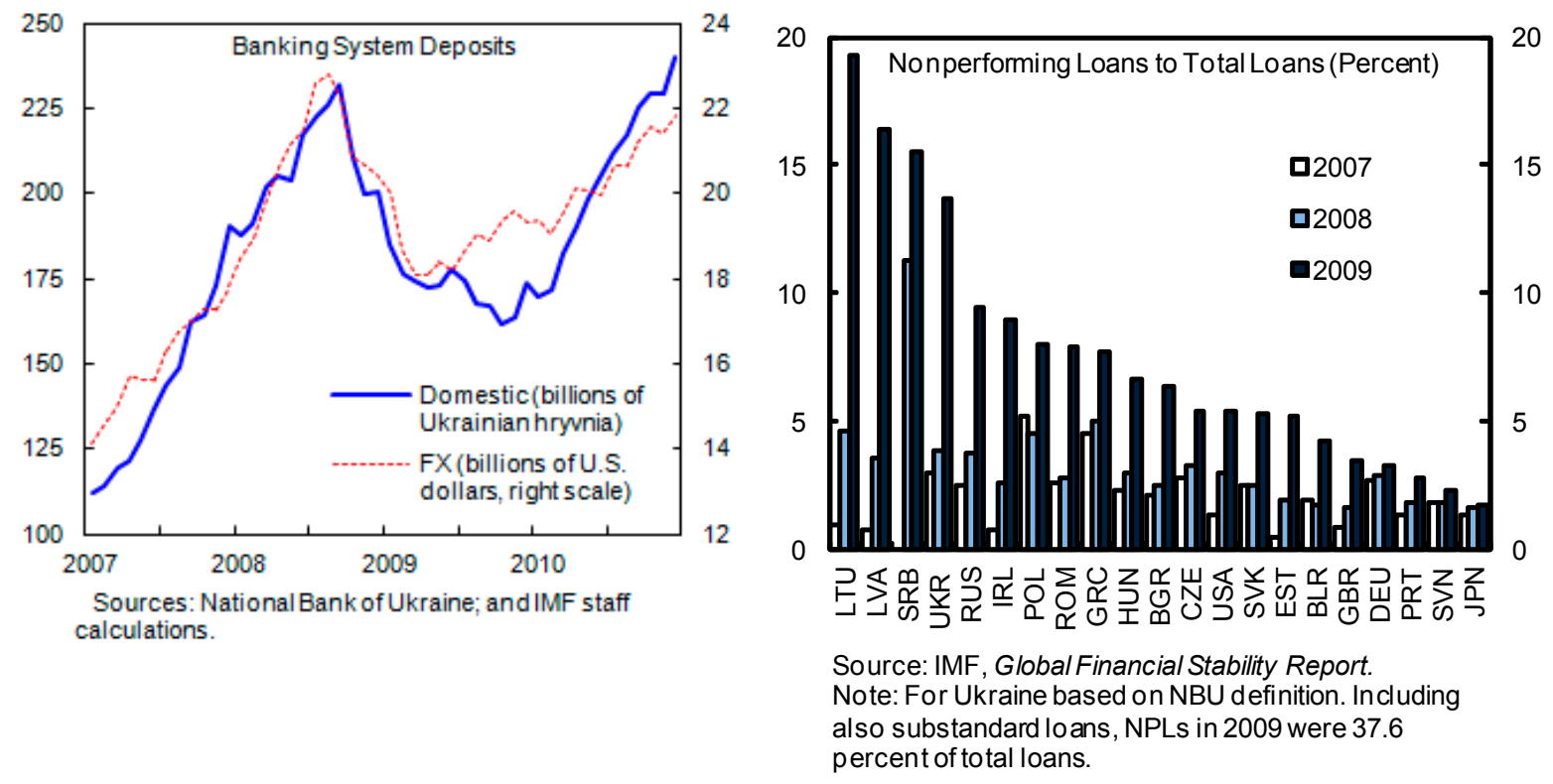

\section{Fiscal Policy}

\section{Significant flexibility in the program design helped strike an appropriate balance between three competing fiscal objectives:}

- Cushioning the impact of the downturn. The program initially targeted a conservative fiscal stance — with a balanced 2009 budget - to strengthen confidence.

However, it also envisaged that fiscal targets would be adjusted, depending on the economic outlook and availability of financing. In practice, and as per most other Fund programs, the 2009 targets were relaxed significantly, reflecting the unexpected large impact of the crisis on

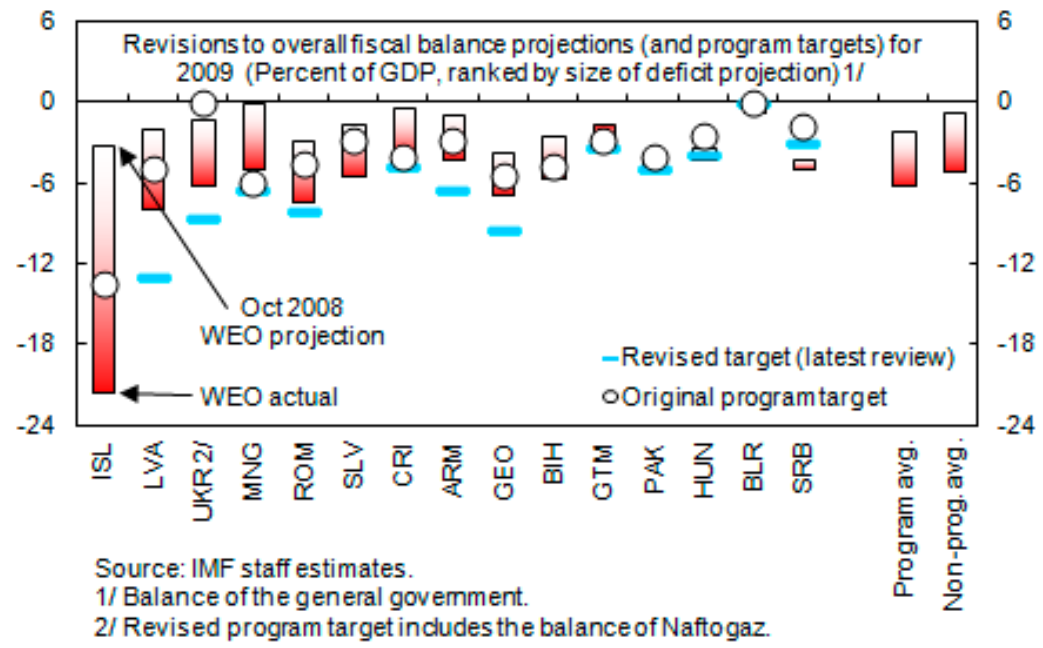
government revenue and 
unforeseen support to Naftogaz. With hindsight, and taking into account the increase in the stock of overdue VAT refunds, the fiscal stance was broadly neutral in 2009, broadly in line with other program cases. ${ }^{6}$

- Coping with a tight financing constraint. A key constraint for the design of the fiscal program was the lack of financing - the international capital markets were virtually closed, and the government could only count on limited Treasury bill issuance and deposits. The channeling of Fund resources to the budget, which became necessary at the time of the first review to avoid a contractionary fiscal stance, was instrumental in avoiding social arrears and a default on government debt. In the second half of 2009, Ukraine's sale of its SDR allocation also alleviated budget pressures.

\section{- $\quad$ Keeping public finances on a}

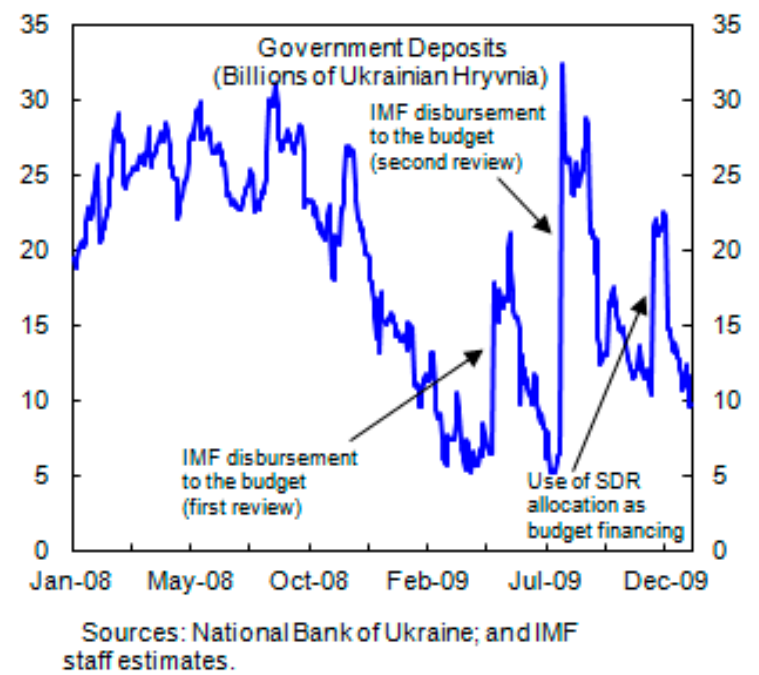

sustainable path. Measures of about 1.6 percent of GDP were implemented in 2009 to stem the increase in the fiscal deficit and government debt. However, with a debtto-GDP ratio of some 12 percent of GDP at end-2007, the government could temporarily absorb considerable foreign and domestic liabilities, including from the banking sector, without threatening fiscal sustainability.

\section{Policy measures appropriately focused on resetting income policies in line with} inflation and aligning energy prices with costs, while protecting social spending. After several years of sharp increases in real wages and pensions, the program supported the government's initial objective of limiting real wage and pension growth. In view of the budgetary impact of the growing gap between domestic energy prices and their costs, it also aimed at addressing underlying problems regarding energy pricing policies, with a particular emphasis in gas prices (Box 3). The social safety net was viewed as broadly adequate to protect the vulnerable against adjustment policies, including housing and utility allowances and a "lifeline" to smaller gas users. In addition, the program accommodated an increase in social expenditure by 0.8 percent of GDP.

\footnotetext{
${ }^{6}$ The cyclically-adjusted general government balance points to a withdrawal of stimulus of about 1 percent of GDP in 2009. However, the fiscal stance was in practice looser, as this does not account for an increase in overdue VAT refunds (1 percent of GDP) and the issuance of bank recapitalization bonds (2 $\frac{1}{2}$ percent of GDP) — which were monetized. The 2009 Review of Recent Crisis Programs (SM/09/249) noted that automatic stabilizers were allowed to come into play in program countries, though not fully as authorities in all countries took measures to contain the widening of deficits.
} 


\section{However, late consultation on the $\mathbf{2 0 0 9}$ budget impeded discussions on} appropriate policies. Against commitments to adopt a program-consistent budget in April 2009 (structural performance criterion), a budget inconsistent with the fiscal objectives was adopted in December 2008, a few weeks after program approval. Measures necessary to bring the fiscal program back on track (of 1 percent of GDP) were eventually agreed upondelaying the completion of the first review - but proper budget discussions could not take place as the budget had become a fait accompli. The program aimed at protecting capital spending, but with hindsight, a large part of the adjustment was borne by government investment, which was substantially reduced compared to the 2009 budget - and more than halved in 2009 compared to 2008.

\section{The program rapidly went off-track, preventing implementation of permanent measures to underpin the necessary medium-term fiscal adjustment. Given the fast} increase in government debt and the use of Fund resources for budget financing, measures to ensure medium-term fiscal sustainability and to reduce dependency on IMF budget support were included in the program. At the time of the second review, the authorities committed to limit the general government deficit (including transfers to Naftogaz) to 4 percent of GDP in 2010. The adjustment was to be underpinned by quarterly gas prices increases and tax and pension reform, for which a time-bound roadmap had been announced. However, the government eventually backtracked on the gas price increases which had been announced as a prior action for second review, and the political consensus in favor of program-supported policies gradually vanished ahead of the presidential election. The government submitted to parliament in mid-September a draft 2010 budget that implied a general government deficit of about twice the targeted level; a social standards law that was estimated to imply higher expenditure of between $2 \frac{1}{2}$ and 7 percent of GDP (depending on the wage indexation system) was enacted; wage top ups were granted to certain categories of employees; and no progress was made on fiscal structural reforms.

\section{Although conditionality could have been strengthened to foster better program} implementation, weak performance mainly reflected the lack of ownership. There could have been room to seek more frontloading of structural measures and to increase the number of structural conditions in the fiscal area, including prior actions. However, political wrangling and interference weakened ownership considerably. As a result, conditions under the program often reflected difficult trade-offs between ensuring the success of the program, limiting the social impact of the crisis, and ensuring political support in a fragmented political environment. 


\section{Box 3. Naftogaz and the 2008 SBA}

The increase in quasi-fiscal deficits in the run-up to the financial crisis and a lack of transparency undermined Naftogaz' (NG) financial viability. With the gradual phasing out of subsidies by Russia, gas import prices had increased substantially since 2006, while domestic heating tariffs and gas prices for households and utilities had only increased marginally. Faced with mounting losses, hit by the financial crisis, and in technical default on its Eurobonds for failing to publish audited 2007 accounts, NG found it more difficult to access financing.

The 2009 gas crisis erupted against this background. By end-2008, NG had accumulated significant gas arrears to Gazprom, and disagreements over the future gas imports and transit pricing were looming. The dispute erupted in January, causing disruptions in the supply of Russian gas to Ukraine, as well as to the Balkans and Central Europe. It was resolved after NG repaid its outstanding debt to Gazprom, and a new ten-year gas contract was signed in early February.

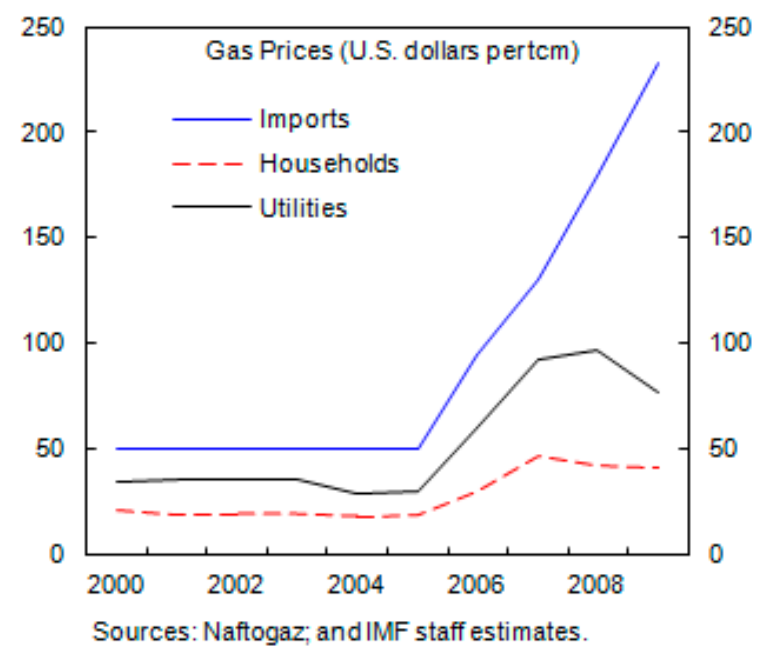

The program aimed at securing greater transparency and financial stability in Naftogaz, but there were significant policy slippages. The program focused on the following three areas:

- Adjusting domestic gas and heating price toward cost-recovery. The authorities initially committed to a gradual phasing-out of gas subsidies over three years and heating subsidies over $1 \frac{1}{2}$ years. The program also aimed at reforming the regulatory framework to reduce political interference. However, gas prices were only increased once (by 35 percent) in late 2008. As a result, gas prices for households and utility companies respectively accounted for about one-fifth and one-third of import prices by end-2009. Gas prices were reduced for some specific industries in 2009. Heating tariffs remained broadly unchanged, and no progress was made on the regulatory framework.

- Broadening the scope of fiscal targets to include NG. At the time of the second review, it had become clear that government support to NG was going to be large and take various formsdirect cash transfers, recapitalization bonds (in turn monetized by the NBU), government guarantees, State bank lending, and tax offsets. To capture these various forms of financial support, a combined deficit target for the general government and NG was introduced. This was a significant step toward greater transparency, especially as the program included a regular independent assessment of NG's cash flow situation by a reputable international auditor.

- Supporting other modernization reforms, including the initiation of a restructuring strategy for Naftogaz and a mechanism for the transparent financing of gas transit modernization needs.

Overall, the gas sector represented a significant drag for public finances during the program period. In addition to the direct budget transfers to NG (0.8 percent of GDP in 2008, and 0.5 in 2009), support to NG unforeseen at the time of the program amounted to roughly 4 percent of GDP. This included the recapitalization of a State bank (1.2 percent of GDP in late 2008) to finance the payment of gas arrears, recapitalization bonds (2.7 percent of GDP in 2009), and government guarantees (1.4 percent of GDP in late 2009) to support the restructuring of its external liabilities. 


\section{Exchange Rate and Monetary Policy}

\section{Moving to a flexible exchange rate regime was the pillar of exchange rate and} monetary policy program design, but implementation resembled a step devaluation. For years, the Fund had recommended shifting from a peg to the U.S. dollar to a more flexible exchange rate with a view to gaining better control over inflation, facilitating adjustment to external shocks, as well as discouraging dollarization and excessive risk taking by unhedged borrowers. While substantial technical assistance was provided, weak political willingness brought little progress prior to the crisis. This did not change fundamentally during the program. Although the official hryvnia rate depreciated strongly, policies deviated in many respects from those agreed upon.

\section{Assessing the role of the exchange rate policy can be structured along three} questions: (i) was the program's strategy to moving to a more flexible exchange rate appropriate; (ii) what did the exchange rate policy achieve; and (iii) what were the implications from the deviations in policy implementation?

- Under the circumstances, greater exchange rate flexibility was preferable to other alternatives. An exchange rate adjustment was unavoidable given the nature of the shock, despite its balance sheet effects for the private sector that was largely indebted in foreign currency. Step devaluations or a gradual widening of the band were considered but would have been too risky given the large degree of uncertainty about the size and duration of the shocks and in light of the level of reserves.

- The exchange rate adjusted - but was largely flexible only for a brief periodcontributing to closing the balance of payments gap. After the initial disbursement, the authorities intervened heavily for about two weeks, contrary to their commitment under the program, before letting the currency depreciate. From end-December 2008, the hryvnia was de facto re-pegged but all NIR targets were met and interventions slowed down. ${ }^{7}$ Overall, the real effective exchange rate depreciated by about 30 percent from peak to trough, similar in size to past crises episodes worldwide. However, about half of the adjustment corrected the sharp pre-crisis real appreciation. Accounting for this, the REER development was broadly in line with other program

\footnotetext{
${ }^{7}$ In late 2009, Fund staff was informed by the NBU that data reported under the NIR performance criterion had been inaccurate. Specifically, non-G-7 securities holdings - consisting of high quality EU member state securities - had been included in calculating the gross international reserve assets component of NIR, contrary to the definition in the Technical Memorandum of Understanding (TMU). On July 28, 2010, the IMF Executive Board granted waivers of nonobservance of the missed performance criterion with respect to the related noncomplying purchases on the basis of the minor economic effect of the application of an incorrect definition. The inaccurate reporting also gave rise to a breach of obligation under Article VIII, Section 5. However, in view of the understandings reached between the staff and the authorities to modify the definition of NIR under the new proposed SBA, no further remedial action was required.
} 
countries during the current crisis, and facilitated a relatively swift narrowing of the current account deficit.

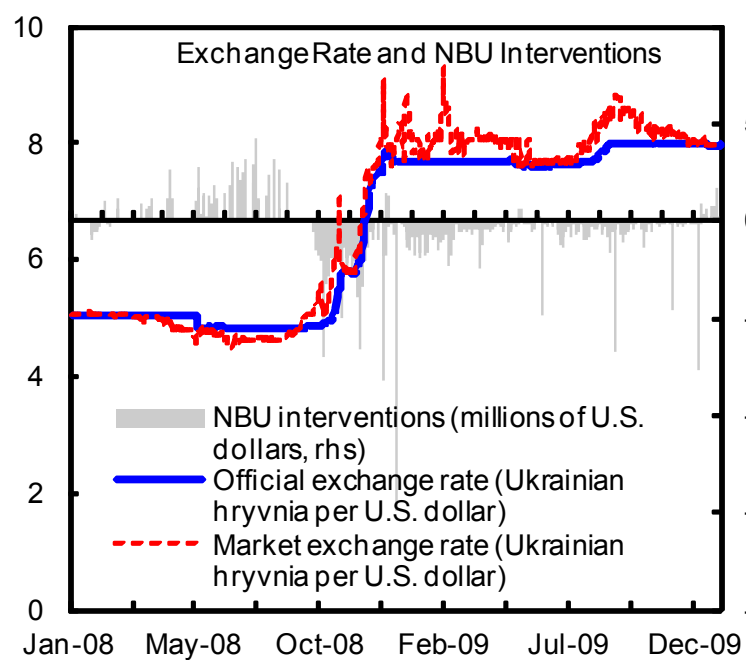

Sources: National Bank of Ukraine; Bloomberg; and IMF staff estimates.

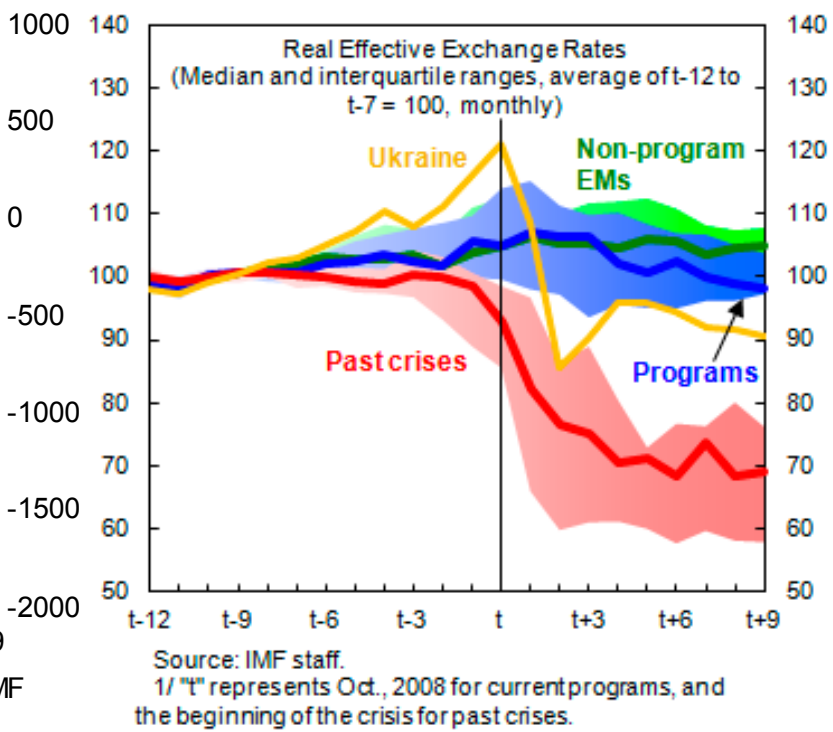

\section{- Weaknesses in program implementation eventually did not impede economic} adjustment but were associated with distortions. The authorities reneged several times on their commitment to reduce the deviation of the official from the market rate, which also breached the performance criterion on nonintroduction of multiple currency practices. Before the completion of the second review, the alignment was temporarily achieved, however, through heavy moral suasion for setting the market rate. Removal of the foreign exchange transaction tax, a structural benchmark, was not completed under the program. Together with restrictions on forward operations, it inhibited the

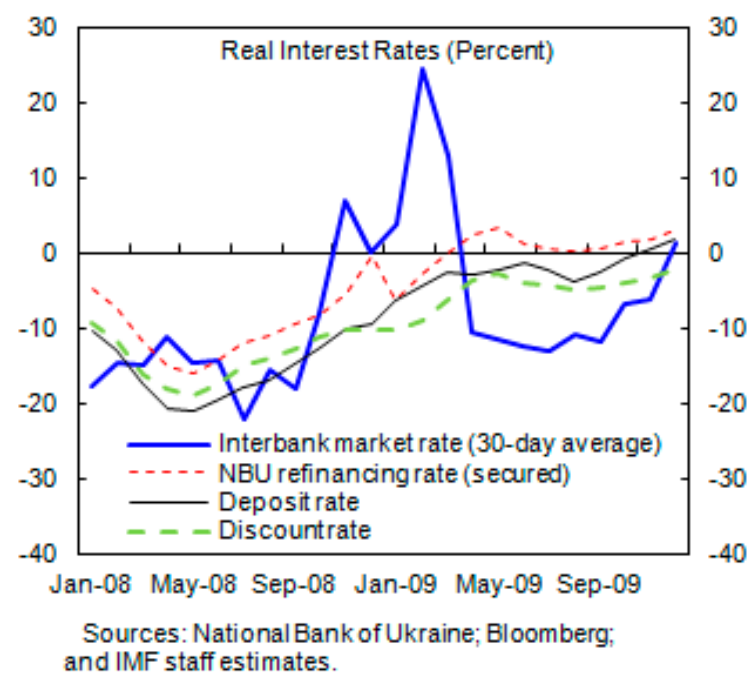
development of a derivatives market. Other exchange controls, which were mostly put in place before the program was approved, did neither prove particularly effective nor macro-critical and were thus agreed to be phased out. ${ }^{8}$

\footnotetext{
${ }^{8}$ For example, the limits on the withdrawal of time deposits before maturity could only partially stem overall deposit outflows. Before the first review, the authorities also temporarily adopted import surcharges on a number of commodities, against the advice of the Fund, but later agreed to limit them to two products.
} 
38. Monetary policy was broadly appropriate and high pre-crisis inflation reined in (Appendix Table 4). Base money targets provided initially a new anchor for monetary policy and quantitative performance criteria were comfortably met as sufficient room was allowed from the start for NBU liquidity support to the banking system. As output collapsed more than expected and the global crisis pushed commodity prices down, the high pre-crisis levels of inflation started to come down quickly despite the sharp hryvnia depreciation. Except for a temporary loosening of monetary policy in early January 2009, against IMF advice, the main policy interest rate was kept low but slightly positive in real terms (and more positive if one considers the expected decline in inflation). Little progress, however, was made toward moving to an inflation targeting regime, which was one of the medium-term program objectives. As the exchange rate de facto took over again the monetary policy anchor role, structural challenges deriving from the exchange rate regime have become further engrained. Also, the large amount of liquidity support (Section IV) at extended maturities will complicate monetary policy going forward.

\section{CONCLUSIONS AND KEY LESSONS}

39. The crisis left deep marks in Ukraine's economy, even more so than in many other program countries. With real GDP dropping by 14.8 percent in 2009, it experienced one of the sharpest downturns in the current global crisis and also when compared to past crises (Appendix Figure 1). Inflation came down quickly in 2009 as domestic demand dropped - only partially slowed by the exchange rate pass-through — but remained above that in other program countries. At the start of the crisis, its level of external debt was higher and its reserve coverage lower than in other program countries. This gap widened during the crisis. The deep recession combined with the banking crisis and transfers to Naftogaz also strained Ukraine's fiscal position more than in many other countries and raised its originally low public debt ratio to that of the average of program countries. Ukraine's current account imbalance, however, was smaller than in comparators and adjusted somewhat more quickly.

40. Nevertheless, the program helped avoid even more severe macroeconomic distortions in the short term. Preventing a financial meltdown and re-establishing confidence in the banking system are key achievements of the program and its design. A bank recapitalization and resolution process was set in motion under the program and regulatory and legal tools strengthened. Moreover, the needed exchange rate adjustment facilitated a remarkable turnaround in the current account balance and, combined with high rollover rates, resulted in a stronger-than-expected reserve position at the end of 2009. Budget support and the adjustment of the deficit targets in light of new information about the economy helped to avoid budgetary arrears in social spending, although VAT refund arrears emerged in the second half of 2009, and cushioned an even sharper demand shock. Moreover, through its close engagement, the Fund influenced some policy proposals that may have created even larger distortions. It also contributed to capacity building, beyond technical assistance, including in areas such as data collection and analysis (e.g., for monitoring of banks and Naftogaz). 
Vulnerability Indicators at Launch and End of SBA

(Ratio between end-2009 (end-2010) and end-2008; closer to center = improvement)

External and Financial Indicators

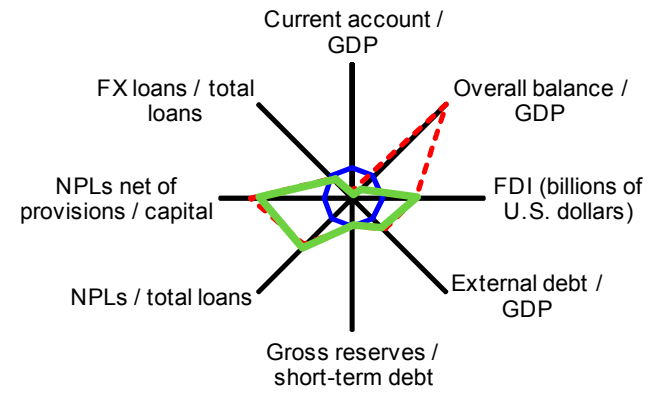

_- Launching of SBA (2008)
End of SBA (2009)
End-2010

Source: IMF staff reports and staff calculations.
Fiscal Indicators

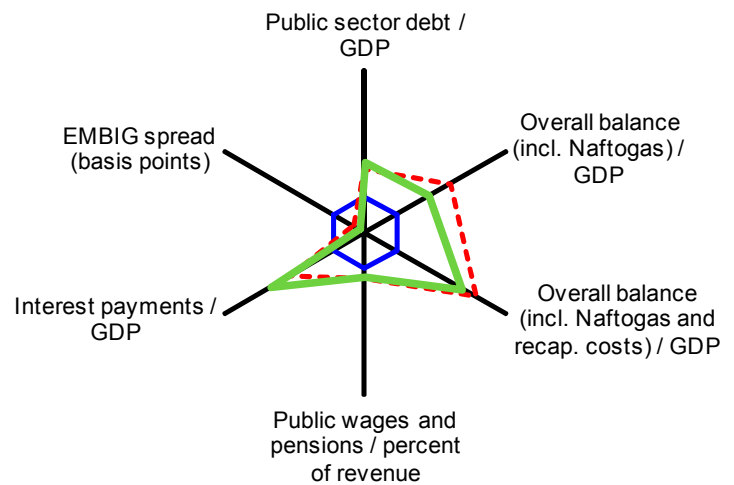

41. But little ownership and overall weak policy implementation prevented better outcomes and tackling fundamental structural and institutional weaknesses, leaving Ukraine with core medium-term vulnerabilities. The bank recapitalization and resolution process proceeded more slowly than envisaged under the program and was not completed. Issues of unevenness and lack of transparency persisted. Liquidity support to potentially nonviable banks and extension of maturities may imply future costs and complicate monetary policy. Banking sector regulation and legislation as well as supervision need to be strengthened further. Also, little was achieved under the program with regard to fostering the framework for household and enterprise debt restructuring, NBU governance reform, and shifting to a new exchange rate regime as the exchange rate was de facto re-pegged to the U.S. dollar and regulatory impediments not removed under the program. Also, the energy sector remained largely unreformed with quasi-fiscal deficits widening and adding to the strains on Ukraine's public finances. Fundamentally, under the program no major shift in policy making occurred but the focus was on short-term crisis management, which put the program from the beginning under great pressure to disburse. Large vulnerabilities and distortions remained in place as political economy considerations continue to drive policy making in Ukraine. Addressing these and the remaining adjustment needs is the core of the new program approved by the Board in July 2010.

42. In summary, the experience with the 2008 SBA has provided some important lessons, but also raised important questions and highlighted difficult trade-offs.

\section{- How can program ownership be strengthened?}


- Four signatories of the program - a unique feature among Fund-supported programs - many prior actions, and close Fund engagement could only provide limited assurances of policy implementation.

- Prior actions helped move the policy agenda forward only in some areas while in others the authorities later reneged (e.g., on a flexible exchange rate, fiscal policy, gas price increases). Despite their limited coverage and reversibility of measures, the program had to rely strongly on them also in light of the Fund's new conditionality guidelines. Compared to structural performance criteria, prior actions - which were used with the same objectives - have no clear test dates scheduled sufficiently ahead of a program review. The continuous "urgency mode" of program discussions also complicated assessing whether they were implemented in spirit and in a durable manner. At a minimum, for technically complex prior actions the informal "five-day rule" for prior actions should be applied and considered to be extended.

- Less front-loading of the program may have provided a better incentive structure but would have to be balanced against the need to stem a sharp confidence crisis. Clearly, the program faced a trade-off between lending into a risky environmentthough it appropriately took a range of measures to enhance ownership - and the need to reestablish confidence with the help of a large and front-loaded financing package. Given the achievement of its main short-term goals of crisis management, it is difficult to argue against this decision, even if it was associated with weak policy implementation and unaddressed structural vulnerabilities.

- What is the appropriate program horizon when key objectives are short term and ownership is weak? The 24-month horizon aimed to obtain ownership beyond the cycle of the current government, provide sufficient support against the exceptional uncertain global environment, and allow addressing structural vulnerabilities. A shorter horizon may have better reflected the political realities, been more explicit about the crisis management focus of the program, and possibly helped to further front-load program design in line with front-loaded financing. It is unlikely, however, to have impacted implementation.

- What should be the coverage of fiscal accounts? With fiscal strains emerging from transfers needed for Naftogaz, the fiscal balance definition and conditionality was usefully broadened. With key data on public sector enterprises not regularly and timely available in many countries, an expansion of information and data collection would be warranted to capture key fiscal variables for the whole public sector.

- How can donor support be broadened? The close cooperation with the World Bank was instrumental in providing support on the bank resolution strategy. However, with the Fund being the only IFI financially engaged with large amounts to support the 
government's crisis management, pressure on the institution was high. The World Bank with its greater medium-term orientation could more easily withdraw as doubts about reform commitment and weak governance emerged. 


\section{Appendix I. Views of the Authorities}

\section{There was agreement that the program was overall well designed and financing} appropriate, but many objectives could not be achieved due to the extremely polarized political situation. The previous authorities praised the IMF staff team's professionalism and dedication in swiftly putting together an IMF-supported program, providing continuous technical support, as well as acting as a mediator between the political factions with a view to forging workable compromises. The size of the program was deemed appropriate even if some initially had envisaged a larger package. The willingness of the IMF to provide budget support was welcomed. Avoiding a sovereign default, stabilizing the banking system, restoring gradually economic growth, maintaining social spending, reducing the current account deficit, and lowering inflation were seen as the main achievements of the program. Views continued to differ, however, on some policies, in areas such as the use of recapitalization bonds, foreign exchange interventions, and gas price increases. But there was agreement that due to the sharp political tensions implementation focused on immediate crisis measures without adopting longer-term structural reforms, except for preparing draft amendments to the NBU Law.

The gas crisis was seen to have left a legacy burden for Ukraine's economy and its government budget going forward. Many considered the gas import prices agreed with Russia in early 2009 as too high and indicated that stronger support by the EU and the international community may have led to a more favorable outcome from a Ukrainian perspective, and consequently easing the impact on Naftogaz' financing gap and the pressure to raise gas prices.

The previous authorities drew some lessons for future involvement. To ensure stronger policy implementation in future IMF-supported programs, they argued for the use of strong and wide-ranging prior actions. This should include full implementation of actions before disbursements, more detailed and specific formulation of measures and concepts in the Memorandum of Economic and Financial Policies and Technical Memorandum of Understanding - setting clear boundaries of non- acceptable policies - and expanding the scope of measures also into areas that have typically been the territory of the World Bank, for example reforms to improve the business climate, since the IMF with its larger financial support was seen to have greater leverage. 


\section{Appendix Table 1. Ukraine: Quantitative and Continuous Performance Criteria}

(End of period; millions of hryvnia, unless otherwise indicated)

\begin{tabular}{|c|c|c|c|c|c|c|c|c|c|c|c|c|}
\hline & \multirow[t]{2}{*}{ Sep. 2008} & \multicolumn{2}{|c|}{ Dec. 2008} & \multicolumn{2}{|c|}{ Mar. 2009} & \multicolumn{2}{|c|}{ May 2009} & \multirow{2}{*}{$\begin{array}{l}\text { Jun. } 2009 \\
\text { Program } \\
\text { PC }\end{array}$} & \multicolumn{2}{|c|}{ Sep. 2009} & \multicolumn{2}{|c|}{ Dec. 2009} \\
\hline & & $\begin{array}{l}\text { Program } \\
\text { PC }\end{array}$ & Actual & $\begin{array}{c}\text { Program } \\
\text { PC }\end{array}$ & Actual & $\begin{array}{c}\text { Program } \\
\text { PC }\end{array}$ & Actual & & $\begin{array}{l}\text { Program } \\
\text { PC }\end{array}$ & $\begin{array}{l}\text { Adjusted } \\
\text { PC }\end{array}$ & $\begin{array}{l}\text { Program } \\
\text { PC }\end{array}$ & $\begin{array}{l}\text { Adjusted } \\
\text { PC }\end{array}$ \\
\hline \multicolumn{13}{|l|}{ I. Performance criteria } \\
\hline Ceiling on the cash deficit of the general government (- implies a surplus) $2 / 3 / 4 / 5 / 6 /$ & $-4,994$ & 9,330 & 30,026 & 0 & 11,040 & 22,500 & 22,500 & $-2,000$ & $-5,000$ & 40,000 & 0 & 55,000 \\
\hline Ceiling on the cash deficit of the general government including Naftogaz (- implies a surplus) $2 / 3 / 4 /$ & n.a. & n.a. & n.a. & n.a. & 10,097 & n.a. & 21,847 & n.a. & 58,600 & 58,600 & 79,100 & 79,100 \\
\hline Floor on net international reserves of the NBU (in millions of U.S. dollars) & 37,530 & 26,700 & 27,811 & 21,800 & 22,238 & 19,700 & 20,799 & 18,700 & 16,600 & 16,600 & 14,900 & 14,900 \\
\hline Ceiling on base money & 170,835 & 190,000 & 186,671 & 192,000 & 174,764 & 193,000 & 181,681 & 197,500 & 203,000 & 210,000 & 211,000 & 211,000 \\
\hline
\end{tabular}

II. Continuous performance criteria

Prohibition on the imposition or intensification of restrictions on the making of payments and transfers for current international transactions Prohibition on the introduction or modification of multiple currency practices

Prohibition on the conclusion of bilateral payments agreements that are inconsistent with Article VIII

Prohibition on the imposition or intensification of import restrictions for balance of payments reasons

III. Adjusters

Project financing 21

Cost of bank recapitalization $3 /$

Stock of budgetary arrears on social payments 4

\begin{tabular}{rrrrrrrrrrrr}
284 & 1468 & 799 & 1045 & 324 & 1050 & 1050 & 2091 & 3,136 & 1,568 & 4,182 & 2,091 \\
0 & 0 & 0 & 0 & 0 & 0 & 0 & 0 & 0 & 0 & 0 & 0 \\
n.a. & n.a. & 76 & n.a. & n.a. & 100 & 100 & n.a. & n.a. & 100 & n.a. & 100 \\
\hline
\end{tabular}

Sources: Ukrainian authorities; and IMF staff estimates and projections.

1/ Definitions are specified in the Technical Memorandum of Understanding (TMU).

$2 /$ The ceiling on the cash deficit of the general government will be adjusted downward by the amount that project financing falls short of the projections. The quarterly ceilings are set taking into account the seasonality of the deficit.

$3 /$ The ceiling on the cash deficit of the general government will be adjusted upward by 100 percent of the fiscal cost of banks recapitalization. This cost includes both the upfront cost for the budget as well as associated subsequent interest payments.

4/ The ceiling on the cash deficit of the general government will be adjusted downward by the amount that budgetary arrears on social payments exceed the projections; respect of the ceiling will be monitored on a quarterly basis.

5/ Data are cumulative flows from January 1 of the corresponding year.

6/ Excluding any bonds issued for capitalization of Naftogaz.

7/ Performance criterion introduced at the time of the second review. 


\section{Appendix Table 2. Ukraine: Prior Actions, Structural Conditionality, and Benchmarks}

Financial Sector

Status

Prior Actions

Initial SBA A.2 Issue a Law or Decree laying out the terms of financial support to banks.

A.3 Make the necessary legal amendments authorizing the NBU to undertake the necessary bank resolution process, including (i) purchase and assumptions, (ii) sales of part or whole bank, and (iii) reduction in the value of the existing shareholders' equity and voting rights to absorb the losses incurred in the resolution process.

A4. Finalize the resolution of the Prominvest Bank.

Met

Met

Met (later reversed

since strategic

investors could not

inject needed capital)

Met

Met strategy, including provision of adequate liquidity support to banks that are recapitalized.

A3. Adopt resolutions that specify the conditions for NBU to extend liquidity finance to solvent banks with adequate collateral and conditionality, as well as procedures to ensure that NBU refinancing is not provided to potentially insolvent banks.

Second A.1 Amend legislation to enable effective bank resolution. The amendments should include revaluation of Review shareholder capital, transfer of assets and liabilities without prior approval of creditors, simplifying and accelerating the process for bank mergers and acquisitions, enabling the government to provide funds for banks under resolution by the NBU, and definition and disclosure of ultimate controllers of banks.

A.2 Finalize the resolution strategy for each of the systemic problem banks and start implementation. In particular, implement the recapitalization for the three banks which the decision thereto has already been taken, and decide on the expediency of the state involvement in replenishing the capital of the other two banks.

Performance Criteria

Initial SBA B.1 Complete a diagnostic study by December 15, 2008 covering NBU's group 1 banks, coordinated by NBU and with participation of several reputable audit firms. (Mid-December 2008)

B.2 Resolve all problem banks by end June 2009, so that viable banks meet the regulatory minimum capital and nonviable banks are liquidated. (End-June 2009)

Met

Not met, prior action

(A2)

\section{Structural Benchmarks}

Initial SBA B.5 NBU to adopt framework for publication, on monthly and quarterly basis, of detailed bank-by-bank financial information in line with international best practices, to include among other items, detailed balance sheets and income statements, information on bank capitalization and asset quality, with separate information for domestic and foreign currency assets and liabilities. (End-January 2009)

First Review B2. Enact necessary amendments to legislation to: (i) include definition and disclosure of ultimate controllers of banks; (end-May 2009); (ii) enable revaluation of shareholder capital, transfer assets and liabilities without prior approval of creditors, simplifying and accelerating the process for bank mergers and acquisitions, and enabling the government to provide funds for banks under resolution by the NBU, (endMay 2009); and (iii) implement consolidated supervision and provide for supplementary supervision of financial conglomerates. (end-May 2010)

B4. Start publishing detailed information on banks, in particular detailed balance sheets and income statements, information on bank capitalization, ownership and asset quality, with separate information for domestic and foreign currency assets and liabilities. (end-September 2009)

Second B2. Amend the Law of Ukraine "On restoring solvency of a debtor or announcing him/her a bankrupt" and

Review related laws to facilitate voluntary out-of-court rehabilitation and by reducing the scope for excessive appeals. (end- September 2009)

B3. Publish detailed information on banks, in particular detailed balance sheets and income statements, information on bank capitalization, ownership and asset quality, with separate information for domestic and foreign currency assets and liabilities. (end-September 2009)

B4. Finalize the resolution strategy for each of the non-systemic problem banks and start implementation. (end- September 2009)

B6. Develop a set of measures to strengthen the financial sustainability of State banks. (end-September 2009)

B8. Enact necessary amendments to legislation to implement consolidated supervision and provide for supplementary supervision of financial conglomerates (end-May 2010).

Reset (end-September 2009)

(i) and (ii) are not met, prior action (A1, 2nd review)

Program off track

Program off track

Program off track

Program off track

Program off track

Program off track 


\section{Appendix Table 2. Ukraine: Prior Actions, Structural Conditionality, and Benchmarks (concluded)}

\begin{tabular}{|c|c|c|}
\hline & Fiscal Policy & Status \\
\hline \multicolumn{3}{|l|}{ Prior Actions } \\
\hline Initial SBA & -- & \\
\hline \multirow[t]{2}{*}{ First Review } & A1. Revoke Articles 84 and 86 from the 2009 Budget Law & Met \\
\hline & A7. Adopt measures reducing the general government deficit by at least 1 percent of GDP in 2009 . & Met \\
\hline \multirow[t]{2}{*}{$\begin{array}{l}\text { Second } \\
\text { Review }\end{array}$} & $\begin{array}{l}\text { A3. Announce an increase in the price of natural gas paid by households (effective September } 1 \text { ) and } \\
\text { utility companies (effective October } 1 \text { ) by } 20 \text { percent to bring these tariffs at } 31 \text { and } 43 \text { percent of import } \\
\text { prices, respectively, and announce a schedule of } 20 \text { percent quarterly price increases for households and } \\
\text { utility companies starting in January } 2010 \text {. Introduce mechanisms to enforce payment discipline of utility } \\
\text { companies and households. }\end{array}$ & Met \\
\hline & $\begin{array}{l}\text { A4. To improve transparency of Naftogaz: approve a revised } 2009 \text { financial plan and develop a } 2010 \\
\text { projected financial plan for Naftogaz, based on credible financing assumptions, and commission an } \\
\text { independent review, by an international audit firm, to put in place a monitoring framework for the cash } \\
\text { result of the company and to establish regular (monthly) and timely public reporting of key financial data. }\end{array}$ & Met \\
\hline
\end{tabular}

Performance Criteria

Initial SBA B3. Pass a 2009 Budget consistent with our general government deficit target of a zero overall balance. Consistency will be monitored through the target for the state budget deficit and the budgets for the socia funds. (end-April, 2009)

Structural Benchmarks

Initial SBA

First Review

Second

Review

B5. Initiate the implementation of the reform and restructuring strategy for Naftogaz, including a mechanism for transparent financing of gas transit modernization needs, in accordance with the principles of the Brussels declaration. (End-Sept 2009)

Exchange Rate and Monetary Policy

Initial SBA A1. Implement a flexible exchange rate regime. NBU Council to take and publicize a decision to abolish the exchange rate band, and NBU Board to define the official rate as the preceding day's market exchange rate (with intra-day adjustments if necessary to keep it within 2 percent of the market rate)

First Review A4. Publication of a statement by the NBU renewing the commitment to implement a flexible exchange rate regime and a transparent intervention.

A5. Adopt and implement a resolution specifying that the official exchange rate will be set, on a daily basis, at the average transaction-weighted rate of the previous day (with intra-day adjustments if necessary to keep it within 2 percent of the market rate).

A6. Announce a tender for a Special Audit of NBU refinancing and foreign exchange operations in 2008, to be executed by a qualified international audit firm, on the basis of a terms of reference agreed with IMF staff.

Second A5. Improve the functioning of the foreign exchange market, including by amending NBU regulation 108 to Review lift the ban on foreign exchange forward and spot transactions.

Met

Met

Met

Met (but implementation delayed)

\section{Performance Criteria}

Initial SBA,

First, Second

Review

Structural Benchmarks

Initial SBA

Reset (end-September 2009)

B.6 Strengthen NBU independence: reform NBU council, transforming it into a narrower technical body in Reset (end-September line with best practice; prolong the term of the Governor; and provide more financial flexibility to NBU (securitize government debt to the NBU, centralize all liquidity operations in the NBU, and bring profit transfer arrangements into line with best international practice). (end-June 2009)

First Review B1. Ensure de jure and de facto independence of the NBU. Enact legislation to strengthen the overall governance structure of the NBU; in particular, reform the NBU council, transforming it into a narrower technical body and revise the NBU Law as needed to address all safeguards-related weaknesses, as noted by recent safeguards assessment. (end-May 2009)

Second B1. Enact legislation to strengthen the overall governance structure of the NBU council, transforming it

Review into a narrower technical body and revise the NBU Law as needed to address all safeguards-related weaknesses, as noted by the recent safeguards assessment. (end-September 2009)

B7. Eliminate the foreign exchange transaction tax. (end-September 2009)
Reset (end-September

Program off track

Program off track 
Appendix Table 3. Ukraine: Key Political Developments, 2007: Q2-2010: Q2

\begin{tabular}{|c|c|c|}
\hline & Date & Political events \\
\hline \multirow[t]{2}{*}{ Q2-2007 } & 1-Apr-07 & President Yushenko issues a decree to dissolve the parliament. \\
\hline & 5-Jun-07 & The president sets a date for early parliamentary elections. \\
\hline Q3-2007 & 30-Sep-07 & Parliamentary elections; narrow majority for the parties linked to President Yushenko and Yulia Tymoshenko. \\
\hline Q4-2007 & 18-Dec-07 & $\begin{array}{l}\text { New government is formed with Yulia Tymoshenko as prime minister -- with } 226 \text { votes, the minimum number } \\
\text { required to take office. }\end{array}$ \\
\hline \multicolumn{3}{|l|}{ Q1-2008 } \\
\hline \multirow[t]{2}{*}{ Q2-2008 } & 6-Jun-08 & Two deputies quit the coalition depriving it of its majority. \\
\hline & 18-Aug-08 & President's office says Tymoshenko betrays national interests by not backing Georgia in its conflict with Russia. \\
\hline \multirow[t]{2}{*}{ Q3-2008 } & 4-Sep-08 & $\begin{array}{l}\text { President Yushenko's Our Ukraine-People's Self Defense Bloc (OU-PS) withdraws from the governing coalition } \\
\text { after denouncing joint vote by Tymoshenko's bloc and Yanukovich's party. The president threatens to call an } \\
\text { election. Collapse of coalition officially announced September } 16 .\end{array}$ \\
\hline & 17-Sep-08 & Speaker of parliament Yatseniuk offers his resignation. \\
\hline \multirow[t]{6}{*}{ Q4-2008 } & 8-Oct-08 & $\begin{array}{l}\text { President Yushenko issues a decree to dissolve the Rada after parties fail to resurrect a ruling pro-Western } \\
\text { coalition. He calls for early parliamentary election for December } 7,2008 \text {. He later revokes the decree and sets a } \\
\text { new election date for December } 14 \text {. The right of the president to dismiss the parliament was challenged in } \\
\text { Ukraine's Constitutional Court. Ukraine's Prime Minister Tymoshenko says there will be no early parliamentary } \\
\text { elections, defying the presidential decree and raising the stakes in her political battle with the president. The } \\
\text { president's decree lapses. }\end{array}$ \\
\hline & 12-Nov-08 & Paliament dismisses its speaker Yatseniuk. \\
\hline & 9-Dec-08 & $\begin{array}{l}\text { The parties of President Yushchenko and PM Tymoshenko agree to cancel early parliamentary elections and re- } \\
\text { form their coalition government. Ukraine lawmakers forged a three-party coalition ending months of deadlock. } \\
\text { Lytvyn from the Bloc Lytvyn is elected speaker of the Rada. }\end{array}$ \\
\hline & 16-Dec-08 & The coalition agreement is signed. \\
\hline & 24-Dec-08 & $\begin{array}{l}\text { Russian energy giant Gazprom threatens to cut gas deliveries to Ukraine on January } 1 \text { if a new contract is not } \\
\text { signed by then for } 2009 \text { but pledges to honor its supply obligations to Europe. }\end{array}$ \\
\hline & 30-Dec-08 & $\begin{array}{l}\text { The government issues a decree saying two state banks would lend state energy company Naftogaz Ukrainy up } \\
\text { to } \$ 2 \text { billion to pay its arrears to Russia's Gazprom. Disagreements remain on future gas costs. }\end{array}$ \\
\hline \multirow[t]{8}{*}{ Q1-2009 } & 1-Jan-09 & $\begin{array}{l}\text { Russia stops all gas supplies to Ukraine after collapse of talks to end row over unpaid bills and prices, leading to } \\
\text { shortages in southeast Europe. Supplies are restored a week later when Ukraine and Russia sign a 10-year deal } \\
\text { on gas transit. }\end{array}$ \\
\hline & 18-Jan-09 & $\begin{array}{l}\text { Russia and Ukraine announce a deal to end the bitter dispute that has blocked Russian natural gas from Europe } \\
\text { following talks between Russian Prime Minister Putin and his Ukrainian counterpart. New terms for gas imports } \\
\text { and transit are agreed. Yushchenko says the deal clinched by Tymoshenko is a "defeat". }\end{array}$ \\
\hline & Jan-2009 & Minister of Finance Pynzenyk refuses to sign the 2009 budget and goes on sick leave. \\
\hline & 26-Jan-09 & $\begin{array}{l}\text { Parliament voids its } 2004 \text { appointment of NBU Governor Stelmakh due to allegations of corruption. The Governor } \\
\text { goes on leave. }\end{array}$ \\
\hline & 17-Feb-09 & Minister of Finance Pynzenyk resigns. \\
\hline & 3-Mar-09 & Parliament sacks Foreign Minister Volodymyr Ohryzko, a Yushchenko ally. \\
\hline & Early Mar-2009 & NBU Governor Stelmakh is confirmed as governor. \\
\hline & Early Mar-2009 & $\begin{array}{l}\text { Joint public declaration by the president, the prime minister, and the NBU governor reaffirming their commitment } \\
\text { to implement the policies of the IMF-supprted program. }\end{array}$ \\
\hline \multirow[t]{5}{*}{ Q2-2009 } & 1-Apr-09 & Parliament votes to hold presidential elections on October 25 , ending months of uncertainty over the date. \\
\hline & 8-Apr-09 & Umanskyi appointed acting Minister of Finance . \\
\hline & 5-Jun-09 & Parliament dismisses another Yushchenko ally, Defence Minister Yuri Yekhanurov over corruption allegations. \\
\hline & 7-Jun-09 & $\begin{array}{l}\text { Tymoshenko says that talks with the main opposition party on forming a coalition have collapsed, indicating a } \\
\text { continuation of the turmoil that has plagued the country's politics and hobbled its response to the severe } \\
\text { economic crisis. }\end{array}$ \\
\hline & 23-Jun-09 & $\begin{array}{l}\text { Parliament reschedules the date for the election for Sunday January 17, 2010, after Constitutional Court supports } \\
\text { Yanukovitch's appeal on election date. }\end{array}$ \\
\hline Q3-2009 & 1-Sep-09 & $\begin{array}{l}\text { The Verkhovna Rada of Ukraine refused to adopt in the second reading a Law sponsored by the Party of Regions } \\
\text { to increase social standards substantially. }\end{array}$ \\
\hline \multirow[t]{2}{*}{ Q4-2009 } & 20-Oct-09 & Rada approves Social Standards Law. Coalition effectively collapses. \\
\hline & 30-Oct-09 & President Yuschenko signs Social Standards Law into law. \\
\hline \multirow[t]{3}{*}{ Q1-2010 } & 1-Jan, 07-Feb-10 & First and second round of presidential elections. \\
\hline & $25-F e b-10$ & Viktor Yanukowych is sworn into office. \\
\hline & 11-Mar-10 & Azarov selected as Prime Minister and new government formed. \\
\hline
\end{tabular}

Source: IMF staff and Economist Intelligence Unit. 
Appendix Table 4. Ukraine: Selected Economic Indicators, 2008-09

\begin{tabular}{|c|c|c|c|c|c|c|}
\hline & \multicolumn{2}{|c|}{2008} & \multicolumn{4}{|c|}{2009} \\
\hline & $\begin{array}{c}\text { Prog. } \\
\text { Request }\end{array}$ & Actual & $\begin{array}{c}\text { Prog. } \\
\text { Request }\end{array}$ & $\begin{array}{c}\text { First } \\
\text { Review }\end{array}$ & $\begin{array}{l}\text { Second } \\
\text { Review }\end{array}$ & Actual \\
\hline \multicolumn{7}{|l|}{ Real economy (percent change, unless otherwise indicated) } \\
\hline Nominal GDP (billions of Ukrainian hryvias) & 993 & 948 & 1,112 & 990 & 916 & 913 \\
\hline Real GDP & 6.0 & 2.3 & -3.0 & -8.0 & -14.0 & -14.8 \\
\hline \multicolumn{7}{|l|}{ Contributions: } \\
\hline Domestic demand & 14.4 & 7.8 & -14.3 & -22.5 & -29.7 & -25.1 \\
\hline Net exports & -8.3 & -5.8 & 11.3 & 14.5 & 15.7 & 10.3 \\
\hline Unemployment rate (ILO definition; percent) & 6.0 & 6.4 & 9.5 & 9.9 & 10.7 & 8.8 \\
\hline Consumer prices (period average) & 25.6 & 25.2 & 21.0 & 17.2 & 16.3 & 15.9 \\
\hline Consumer prices (end of period) & 25.5 & 22.3 & 17.0 & 16.0 & 14.0 & 12.3 \\
\hline Nominal monthly wages (average) & 37.1 & 33.7 & 10.5 & 4.0 & 3.5 & 5.5 \\
\hline Real monthly wages (average) & 9.1 & 6.8 & -8.7 & -11.2 & -11.0 & -9.2 \\
\hline \multicolumn{7}{|l|}{ Public finance (percent of GDP) } \\
\hline General government balance 1/ & -1.0 & -3.2 & 0.0 & -4.0 & -6.0 & -6.2 \\
\hline Net domestic financing & 1.8 & 2.5 & 4.4 & 5.6 & 5.8 & 1.4 \\
\hline Privatization proceeds & 0.2 & 0.3 & 0.1 & 0.3 & 0.3 & 0.2 \\
\hline Net external financing & 0.0 & 0.4 & 0.0 & 3.2 & 2.6 & 4.7 \\
\hline Overall balance (including Naftogaz operational deficit) 2/ & $\ldots$ & $\ldots$ & $\ldots$ & $\ldots$ & -8.6 & -8.7 \\
\hline Overall balance (including Naftogaz and bank recapitalization costs') & -2.0 & -3.2 & -4.5 & -9.0 & -11.4 & -11.3 \\
\hline Public debt (end of period) $3 /$ & 10.6 & 20.5 & 17.4 & 32.5 & 35.4 & 35.3 \\
\hline Of which: external debt (foreign currency denominated) & 7.4 & 15.8 & 10.0 & 23.1 & 25.0 & 25.3 \\
\hline \multicolumn{7}{|l|}{ Money and credit (end of period, percent change) } \\
\hline Base money & 33.0 & 31.6 & 10.9 & 6.6 & 10.1 & 4.4 \\
\hline Broad money & 37.2 & 30.2 & 9.4 & 3.8 & 1.5 & -5.5 \\
\hline Credit to nongovernment & 40.9 & 71.9 & -9.8 & 7.8 & 3.1 & -2.2 \\
\hline Velocity & 1.8 & 1.8 & 1.9 & 1.9 & 1.8 & 1.9 \\
\hline \multicolumn{7}{|l|}{ Balance of payments (percent of GDP) } \\
\hline Current account balance & -6.2 & -7.1 & -2.0 & 0.5 & 0.6 & -1.5 \\
\hline Foreign direct investment & 6.2 & 5.5 & 6.8 & 4.6 & 3.4 & 4.0 \\
\hline Gross international reserves (end of period, billions of U.S. dollars) & 31.4 & 31.5 & 30.7 & 29.3 & 30.0 & 26.5 \\
\hline Months of next year's imports of goods and services & 5.1 & 6.7 & 4.5 & 5.3 & 5.5 & 4.4 \\
\hline Percent of short-term debt (remaining maturity) & 79.0 & 68.3 & 75.0 & 76.4 & 89.6 & 64.8 \\
\hline Net international reserves (end of period, billions of U.S. dollars) & 26.7 & 27.8 & 14.9 & 14.9 & 14.9 & 15.6 \\
\hline External debt (percent of GDP) & 54.3 & 56.4 & 78.2 & 87.0 & 85.4 & 88.0 \\
\hline Goods exports (annual volume change in percent) & 0.3 & 1.1 & 0.8 & -8.8 & -13.6 & -25.5 \\
\hline Goods imports (annual volume change in percent) & 16.0 & 13.5 & -19.7 & -31.8 & -36.4 & -42.5 \\
\hline Goods terms of trade (percent change) & 7.8 & 10.0 & -14.5 & -13.6 & -13.6 & -13.8 \\
\hline \multicolumn{7}{|l|}{ Exchange rate } \\
\hline Hrymia per U.S. dollar, end of period & $\ldots$ & 7.7 & $\ldots$ & $\ldots$ & $\ldots$ & 8.0 \\
\hline Hrymia per U.S. dollar, period average & $\ldots$ & 5.3 & $\ldots$ & $\ldots$ & $\ldots$ & 7.8 \\
\hline
\end{tabular}

Sources: State Statistics Committee of Ukraine; Ministry of Finance; National Bank of Ukraine; ; and IMF staff estimates and projections.

$1 /$ The general government includes the central and local governments and the social funds. Program numbers exclude interests on bank recap bonds of 0.6 percent of GDP in 2009.

2/ The coverage of the fiscal targets was broadened to include Naftogaz at the time of the second review.

3/ Government and government-guaranteed debt (includes debt to IMF). Program columns excludes IMF disbursements to the NBU. 


\section{Appendix Figure 1. Ukraine: Comparison of Macroeconomic Performance with Other Program Countries}
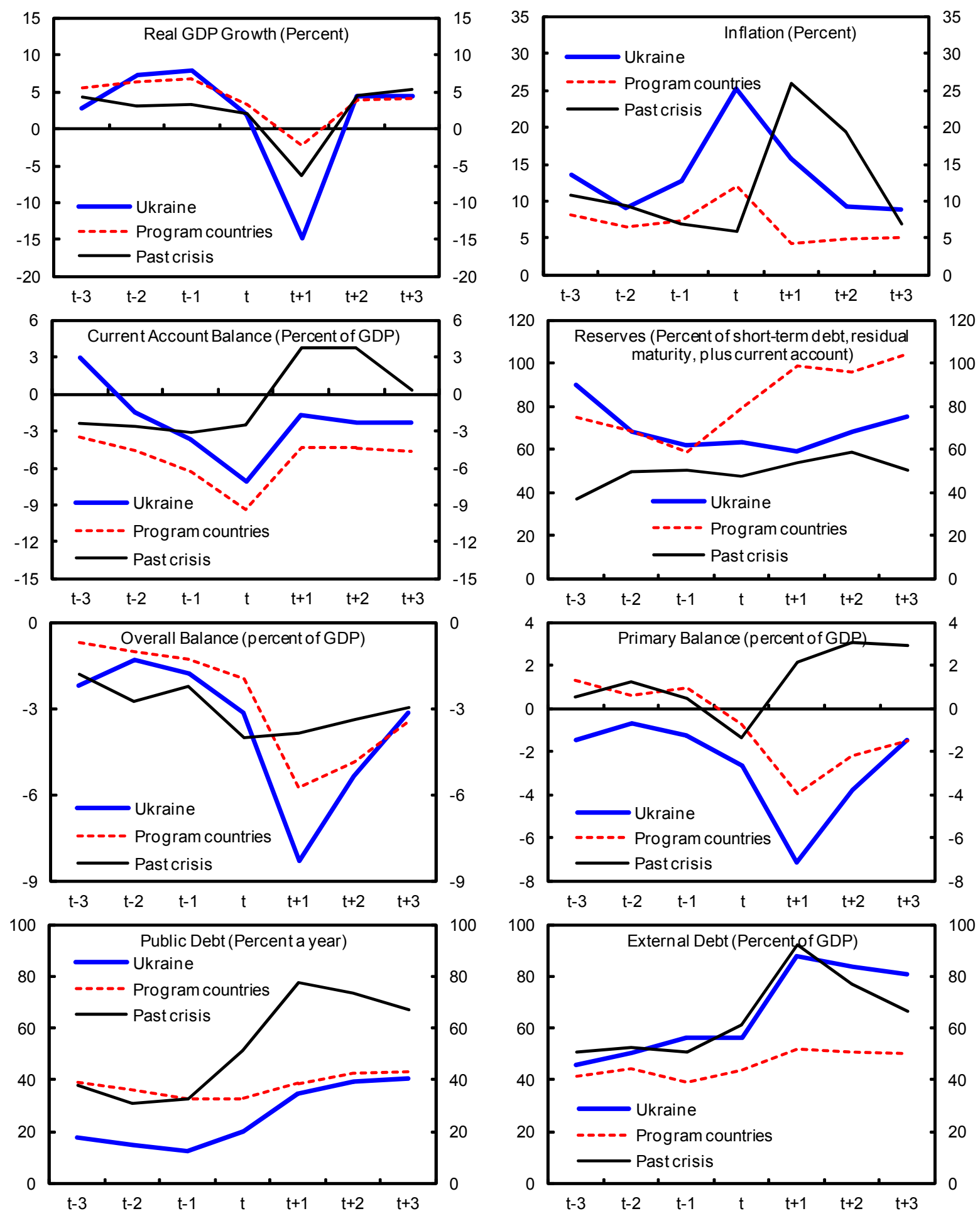

Source: IMF staff. 
Press Release No. 11/407

International Monetary Fund

FOR IMMEDIATE RELEASE

Washington, D.C. 20431 USA

November 11, 2011

\section{IMF Statement on Ukraine}

On November 11, 2011, the Executive Board of the International Monetary Fund discussed the ex post evaluation of the 2008 exceptional access Stand-By Arrangement for Ukraine.

\section{Background:}

In 2002, the IMF Executive Board decided to conduct ex post evaluations of arrangements involving exceptional access to the Fund's General Resource Account. The purpose of these evaluations, which have to be completed within one year of the end of the arrangement, is to provide a critical and frank discussion of whether justifications presented at the outset of the arrangement - including the justification for exceptional access - were consistent with Fund policies and to review performance under the Fund supported program. A staff team prepares a report that is discussed with the country's authorities and presented to the Executive Board for discussion. 